\title{
Leguminosae, Papilionoideae no Parque Estadual do Rio Doce, Minas Gerais, Brasil. II: árvores e arbustos escandentes ${ }^{1}$
}

\author{
Roseli Lopes da Costa Bortoluzzi ${ }^{3}$, Rita Maria de Carvalho-Okano ${ }^{2,3}$, Flávia Cristina Pinto Garcia ${ }^{3}$ \\ Ana Maria Goulart de Azevedo Tozzi ${ }^{4}$
}

Recebido em 02/04/2001. Aceito em 01/07/2003

\begin{abstract}
RESUMO - (Leguminosae, Papilionoideae no Parque Estadual do Rio Doce, Minas Gerais, Brasil. II: árvores e arbustos escandentes). Este estudo relata o levantamento florístico de táxons de Papilionoideae arbóreos e arbustivo-escandentes em floresta semidecídua, no Parque Estadual do Rio Doce, localizado ao leste de Minas Gerais. O trabalho de campo foi realizado no período de abril/1998 a maio/1999, quando foram conduzidas visitas mensais para coletas de material botânico ao longo de trilhas e da estrada principal. O levantamento resultou em 22 táxons pertencentes a oito gêneros. São apresentados chave de identificação, descrições, ilustrações e comentários sobre os táxons analisados.
\end{abstract}

Palavras-chave: Leguminosae, Papilionoideae, florística, Parque Estadual do Rio Doce, floresta semidecidual

ABSTRACT - (Leguminosae, Papilionoideae at Parque Estadual do Rio Doce, Minas Gerais, Brazil. II: trees and climbing shrubs). This work is a floristic survey of arboreous and climbing shrub taxa of Papilionoideae in a semideciduos forest at Parque Estadual do Rio Doce, eastern Minas Gerais State. Field work was carried out from April/1998 to May/1999, when montly visits were conducted to collect botanical material along trails and of the main road. The floristic survey resulted in 22 taxa belonging to eight genera. An identification key, descriptions, illustrations and comments on the analyzed taxa are presented.

Key words: Leguminosae, Papilionoideae, floristic, Parque Estadual do Rio Doce, semideciduos forest

\section{Introdução}

A flora brasileira é considerada uma das mais ricas do globo (Giulietti \& Forero 1990), onde se destaca a do Estado de Minas Gerais, com sua notável riqueza específica. Mesmo assim, a flora neotropical, especialmente a da América do Sul, tem sido pouco estudada, fato também relatado para as Leguminosae (Lewis 1987; Lima \& Fortunato 1998). Além disso, as Leguminosae têm se destacado como elementos importantes de muitas comunidades vegetais (alto IVI em trabalhos fitossociológicos) e/ou característicos de diversas fisionomias vegetais.

As Leguminosae, Papilionoideae são caracterizadas pelas folhas geralmente pinadas, na maioria trifolioladas ou plurifolioladas, nunca bipinadas; flores papilionáceas com simetria zigomorfa e corola com prefloração imbricada vexilar; sementes com a região do hilo bem delimitada e radícula com eixo infletido
(Gunn 1981; Polhill 1981), o que as diferencia das Caesalpinioideae e Mimosoideae.

No Estado de Minas Gerais, estudos específicos sobre as Leguminosae são poucos, e particularmente em áreas de mata estão restritos ao de Mendonça Filho (1996) na Estação Biológica de Caratinga, onde esse autor apresentou diagnoses e chaves analíticas para gêneros e espécies. Estudos florísticos, taxonômicos e/ou florístico-sociológicos no Parque Estadual do Rio Doce (PERD) são escassos, restringindo-se aos de Carvalho et al. (1983), Pedralli et al. (1986), Paula (1992), Graçano et al. (1998), Scudeller \& CarvalhoOkano (1998), Gonçalves (2000), Bovini et al. (2001), Lopes et al. (2002) e Bortoluzzi et al. (2003). Sobre Papilionoideae, trabalhos florísticos são poucos (Bortoluzzi et al. 2003). Além disso, os estudos citados anteriormente foram desenvolvidos, em sua maioria, na região sul do PERD, sendo que sua área central encontra-se praticamente inexplorada cientificamente.

\footnotetext{
1 Parte da Dissertação de Mestrado da primeira autora. Curso de Pós-Graduação em Botânica, Universidade Federal de Viçosa, Viçosa, MG, Brasil

2 Autor para correspondência: Rita Maria de Carvalho-Okano (carvalho@ufv.br)

3 Departamento de Biologia Vegetal, Universidade Federal de Viçosa, CEP 36571-000, Viçosa, MG, Brasil (rosebortoluzzi@ibest.com.br; carvalho@ufv.br; fcgarcia@ufv.br)

4 Departamento de Botânica, Instituto de Biologia, Universidade Estadual de Campinas, CEP 13083-970, Campinas, SP, Brasil (anatozzi@unicamp.br)
} 
Este trabalho teve como objetivos o levantamento dos táxons arbóreos e arbustivo-escandentes de Papilionoideae ocorrentes na região central do PERD; a elaboração de chave analítica para identificação dos táxons específicos e infraespecíficos, descrições e ilustrações dos mesmos.

\section{Material e métodos}

Área de estudo - o Parque Estadual do Rio Doce (PERD) localiza-se no Estado de Minas Gerais (19²9'$19^{\circ} 48^{\prime}$ 'S e $42^{\circ} 28^{\prime}-42^{\circ} 38^{\prime} \mathrm{W}$ ), compreendendo os municípios de Timóteo, Marliéria e Dionísio, na confluência dos rios Piracicaba e Doce (Fig. 1). Fundado em 1944, possui aproximadamente 36.000ha e faz parte da Reserva da Biosfera da Mata Atlântica. Fitofisionomicamente, a área de estudo, região central do parque, com cerca 5.000ha, apresenta-se em bom estado de preservação, estando enquadrada como Mata Alta Primária com Epífitas (Gilhuis 1986).

Coleta e tratamento do material botânico - foram realizadas visitas mensais ao PERD no período de abril/1998 a maio/1999. As coletas foram realizadas ao longo de trilhas e da estrada principal, na região central do PERD, sendo 1. Estrada Cava-Grande - Ponte Queimada (estrada que corta o parque); 2. trilha da Garapa Torta; 3. trilha da Lagoa do Meio; 4. trilha do Aníbal; 5. Ponte Queimada; 6. Lagoa do Aníbal e 7. Lagoa do Meio (Fig. 1). Depois de coletado, o material foi identificado e depositado no acervo do Herbário VIC, Departamento de Biologia Vegetal da Universidade Federal de Viçosa e Herbário do PERD.

A nomenclatura morfológica adotada nas descrições foi baseada nos trabalhos de Radford et al. (1974), Rizzini (1977) e Polhill (1981); para venação, Hickey (1973); inflorescências e frutos, Radford et al. (1974) e Lackey (1981). As descrições genéricas basearam-se na amplitude de variação do táxon e as descrições específicas ou infraespecíficas na amplitude de variações morfológicas observadas no material do PERD e, quando necessário, foram complementadas com dados da literatura e de materiais dos seguintes herbários: Universidade Federal de Viçosa (VIC), Parque Estadual do Rio Doce (PERD), Universidade Estadual de Campinas (UEC).

Comentários sobre a morfologia e a distribuição geográfica foram fornecidos após a descrição de cada táxon. As ilustrações foram confeccionadas com o auxílio de um estereomicroscópio e incluíram o aspecto geral do ramo, quando se julgou importante, e partes reprodutivas utilizadas no reconhecimento do táxon, sendo utilizados materiais herborizados e/ou fixados em etanol $70 \%$.

A chave de identificação dos táxons foi elaborada com base no material coletado no PERD, onde foram considerados arbustos escandentes todas as plantas lenhosas, inicialmente eretas e posteriormente com seus ramos escandentes sobre a vegetação, e árvores, todas as plantas lenhosas, eretas e com ramos não-escandentes.

Os nomes dos autores das espécies foram abreviados de acordo com Brumitt \& Powell (1992).

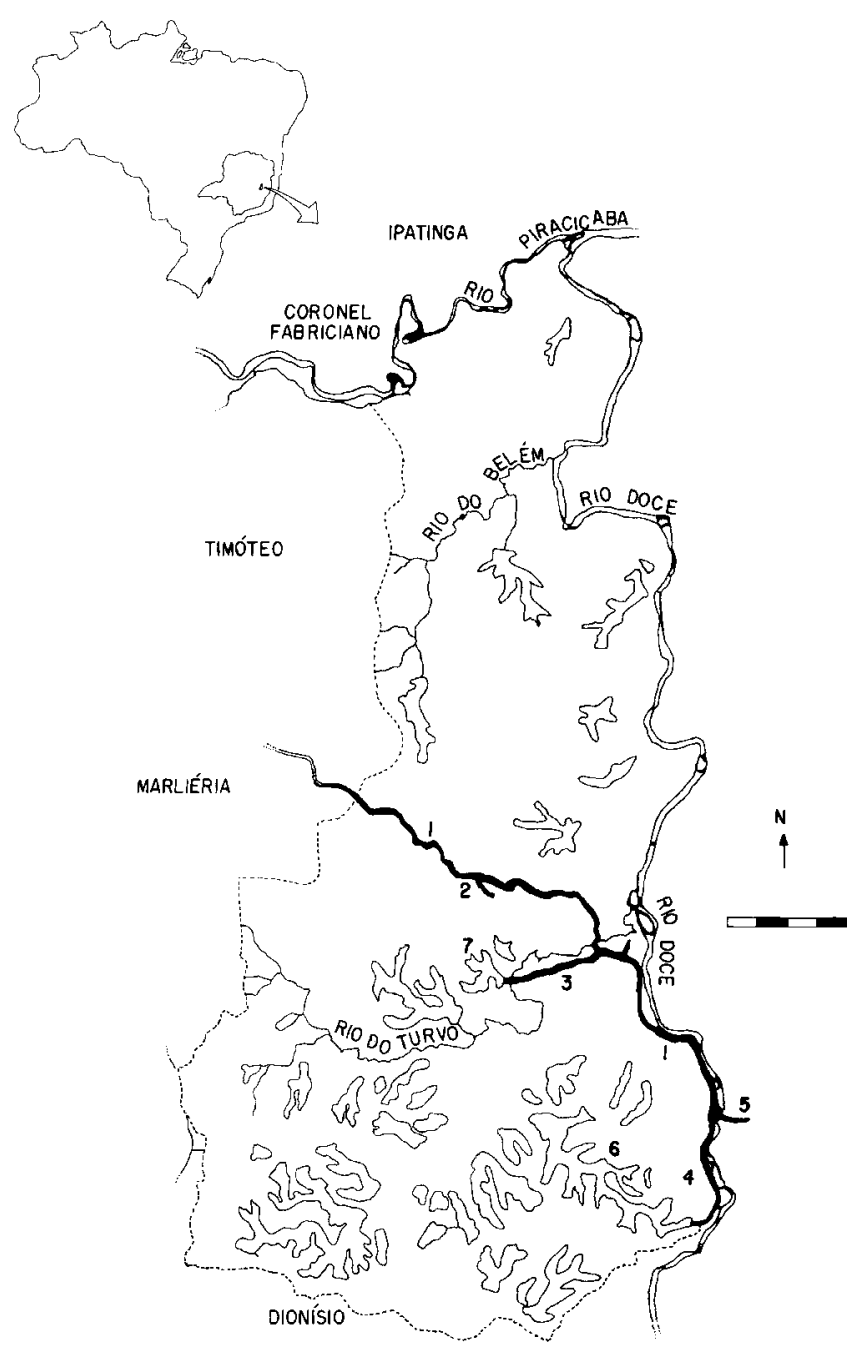

Figura 1. Parque Estadual do Rio Doce (PERD), limitado ao norte e a leste pelos rios Piracicaba e Doce, respectivamente; a oeste pelos municípios de Marliéria e Timóteo e ao sul pelo de Dionísio: 1. Estrada Cava-Grande - Ponte Queimada (estrada que corta o parque); 2. trilha da Garapa Torta; 3. trilha da Lagoa do Meio; 4. trilha do Aníbal; 5. Ponte Queimada; 6. Lagoa do Aníbal; 7. Lagoa do Meio. (modificado de Graçano et al. 1998 e Bertoluzzi et al. 2003; Escala $1: 200.000)$. 


\section{Resultados e discussão}

O levantamento revelou a grande riqueza de Papilionoideae arbóreas e arbustivo-escandentes no Parque Estadual do Rio Doce, somando 22 táxons específicos e infraespecíficos, distribuídos em quatro tribos: Dalbergieae, com cinco gêneros, Dalbergia, Machaerium, Platycyamus, Platypodium e Pterocarpus; Phaseoleae, Milletieae e Swartzieae, com um gênero cada, sendo representadas por Erythrina, Lonchocarpus e Swartzia, respectivamente.

Chave para identificação dos táxons arbóreos e arbustivo-escandentes de Papilionoideae ocorrentes no Parque Estadual do Rio Doce, MG

1. Planta armada

2. Folha com 3 folíolos

3. Pecíolo, raque e nervura mediana dos folíolos com acúleos; corola vermelha; vexilo ca. 5 vezes mais longo do que largo; legume oblongo

2.1. Erythrina speciosa

3. Pecíolo, raque e nervuras sem acúleos; corola laranja-avermelhada; vexilo ca. 1,5 vez mais longo do que largo; folículo subfalcado

2.2. Erythrina verna

2. Folha com mais de 3 folíolos

4. Estípula espinescente retilínea (árvore)

4.4. Machaerium hirtum

4. Estípula espinescente uncinada (arbusto escandente)

5. Folíolo oblongo com ápice retuso

4.1. Machaerium aculeatum

5. Folíolo ovado a elíptico com ápice agudo a acuminado

4.2. Machaerium caratinganum

1. Planta inerme

6. Arbusto escandente

7. Folha com 3 folíolos

4.7. Machaerium ternatum

7. Folha com 5-9 folíolos

8. Inflorescência em cimeira escorpióide; sâmara com região do núcleo seminífero central

8. Inflorescência em racemo ou panícula; sâmara com região do núcleo seminífero basal

9. Folíolo elíptico com ápice acuminado; sâmara falciforme 4.8. Machaerium triste

9. Folíolo oblongo a obovado com ápice geralmente obtuso ou curto-acuminado; sâmara cultriforme 4.5. Machaerium oblongifolium

6. Árvore

10. Folha com 3-9 folíolos

11. Folha com 3 folíolos; folíolo terminal ovado ou romboidal; inflorescência em panícula terminal; corola com 5 pétalas; legume oblongo, plano, ferrugíneo-tomentoso, polispérmico

5.1. Platycyamus regnellii

11. Folha com 3 ou mais folíolos; folíolo terminal elíptico ou amplo-elíptico; inflorescência em racemo ou panícula axilar; corola apétala ou com 1 pétala; legume elíptico ou moniliforme, glabro, mono ou dispérmico

12. Folha com 3-5 folíolos; raque 1-3cm compr.; flor com 1 pétala amarela.

8.4. Swartzia myrtifolia var. elegans

12. Folha com 5-9 folíolos; raque $8-13,5 \mathrm{~cm}$ compr.; flor apétala

8.1. Swartzia apetala var. apetala

10. Folha com 9 ou mais folíolos

13. Folíolos opostos, com estipelas

14. Folha com 9-19 folíolos

15. Corola não-papilionácea com 1 pétala branca; legume nucóide, elíptico ou oblongo, glabrescente 8.5. Swartzia oblata

15. Corola papilionácea com 5 pétalas violáceas; legume oblongo, plano, tomentoso a pubérulo 
14. Folha com mais de 19 folíolos

16. Folíolos de 1,5-2,5cm de compr.; estames maiores com filetes glabros; ovário piloso; fruto globoso ... 8.2. Swartzia flaemingii var. psilonema

16. Folíolos de 2,7-6,7cm de compr.; estames maiores com filetes pilosos; ovário glabro; fruto oblongo . 8.3. Swartzia multijuga

13. Folíolos alternos, sem estipelas

17. Folíolos com venação camptódroma, ápice retuso; sâmara com núcleo seminífero distal 6.1. Platypodium elegans

17. Folíolos com venação broquidódroma, ápice agudo ou acuminado; sâmara com núcleo seminífero central ou basal

18. Corola amarela; sâmara suborbicular a obovada 7.1. Pterocarpus rohrii

18. Corola violácea, creme ou esverdeada, nunca amarela; sâmara elíptica, cultriforme ou falciforme

19. Folíolos oblongos; sâmara elíptica, região do núcleo seminífero central

20. Folíolos com as faces abaxial e adaxial pubérulas; ovário pubescente com tricomas glandulares, estilete quase reto; sâmara subcoriácea, áspera e castanho-alaranjada, quando madura 1.1. Dalbergia foliolosa

20. Folíolos com as faces abaxial e adaxial glabrescentes; ovário ciliado na margem ventral; estilete geniculado; sâmara cartácea, lisa e castanho-escura a vinácea, quando madura . 1.3. Dalbergia nigra

19. Folíolos elípticos, ovados ou obovados; sâmara cultriforme ou falciforme, região do núcleo seminífero basal

21. Folha com 9-13 folíolos; estípula persistente; flor 1-1,3cm compr., corola violácea; sâmara tomentosa a glabrescente, região do núcleo seminífero intumescida e proeminente no fruto maduro 4.3. Machaerium fulvovenosum

21. Folha com 19-25 folíolos; estípula caduca; flor 0,5-0,6cm compr., corola creme ou esverdeada; sâmara glabra, região do núcleo seminífero lisa 4.6. Machaerium stipitatum

1. Dalbergia L.f., Suppl. Pl.: 52. 1781.

Árvore, arbusto escandente ou liana, inerme. Folha imparipinada, plurifoliolada, raramente unifoliolada; estípula caduca; estipela nula. Inflorescência racemosa ou cimosa, geralmente em cimeira escorpióide, axilar ou terminal; bráctea caduca, raramente persistente; bractéola caduca ou persistente. Cálice campanulado, 5-laciniado, lacínios superiores 2, parcialmente unidos, lacínios inferiores 3 , desiguais, sendo o mediano maior que os laterais; corola branca, creme, amarela ou violeta; vexilo ovado, obovado ou orbicular, ungüiculado, glabro; alas oblongas, obovadas ou raramente ovadas, auriculadas na base; pétalas da carena oblongas, às vezes obovadas ou obtusas, fundidas no dorso, levemente menores que as alas; estames mono, di ou poliadelfos, anteras oblongas, deiscência transversal; ovário estipitado; estilete terminal, reto a geniculado; estigma terminal. Sâmara geralmente elíptica, oblonga, linear-oblonga, raramente suborbicular ou orbicular, região do núcleo seminífero central, membranácea a coriácea; monospérmica ou polispérmica.

1.1. Dalbergia foliolosa Benth., J. Linn. Soc. Bot. 4 (Suppl.): 37. 1860.

Fig. 2-10.

Árvore ca. 3-15m alt. Ramo glabrescente, lenticelado. Folha 13-19-foliolada; pecíolo 1-2cm; raque 7,5-14cm; folíolo 1,5-5,5×1,0-1,8cm, alterno, oblongo, base obtusa, ápice obtuso, mucronado, discolor, face adaxial verde escuro e abaxial verde claro, com ambas as faces pubérulas; folíolos basais geralmente menores; venação broquidódroma. Cimeira escorpióide $3,0-5,5(-13,5) \mathrm{cm}$, fasciculada, geralmente intercalada com folhas menores, axilares; bráctea e bractéola caducas. Flor 0,5-1,0cm; pedicelo 0,8-1,0mm; cálice pubescente externamente, glabro internamente; tubo calicino 1,5-1,8mm; lacínios superiores e laterais semelhantes no tamanho, 0,8-1,0mm; lacínio mediano 1,2-1,3mm; corola creme; vexilo 8,0-10mm, obovado; 
alas $8,0-9,5 \mathrm{~mm}$, oblongas; pétalas da carena $6-8 \mathrm{~mm}$, semelhantes às alas, falcadas; estames monadelfos 9; ovário estipitado, estípite 1,5-2,0mm, pubescente com tricoma de base dilatada; estilete quase reto, glabro. Sâmara 3,5-7,5×1,2-1,5cm, estípite 4-8mm, elíptica, plana, subcoriácea, áspera, verde quando imatura e castanho-alaranjada quando madura, superfície com tricomas dilatados na base e enegrecidos; monospérmica, raramente com 2 ou 3 sementes.

Material examinado: BRASIL. Minas Gerais: Marliéria, PERD, às margens da Lagoa D. Helvécio, X/1996 (fr.), Lopes 147 \& Scudeller 604 (VIC); próximo à Casa de Tábua, II/1998 (fl.), Lopes \& Silva 527 (VIC); III/1998 (fr.), Bortoluzzi et al. 43 (VIC, PERD); às margens da Lagoa D. Helvécio, IV/1998 (fr.), Lopes 547 (VIC); margem da Lagoa do Bispo, X/1998 (fr.), Bovini 1553 (VIC); margem da Lagoa de Porto Capim, V/1999 (fr.), Bortoluzzi et al. 634 (VIC).

Dalbergia foliolosa é facilmente reconhecida por apresentar folíolos alternos, oblongos com ápice obtuso e mucronado; ovário pubescente com tricomas glandulares (Fig. 9 e 10), estilete quase reto e sâmara castanho-alaranjada, subcoriácea, áspera com tricomas glandulares de base dilatada. Distingue-se de D. nigra (Vell.) Alemão ex Benth., a espécie mais próxima, pelos folíolos que são menores (1,2-2,5cm compr.), com ápice obtuso a retuso; ovário ciliado na margem ventral; estilete geniculado (perpendicular ao ovário) e sâmara castanhoescura a vinácea, lisa e glabra. D. foliolosa é citada por Carvalho (1997) para os Estados da Bahia, Rio de Janeiro, São Paulo, Minas Gerais e para a região central do Brasil.

1.2. Dalbergia frutescens (Vell.) Britton., Bull. Torrey Bot. Club 16 (12): 324. 1889.

Pterocarpus frutescens Vell., Fl. Flum. 302. 1829.

Fig. 11-12.

Arbusto escandente. Ramo glabrescente, lenticelado. Folha 7-9-foliolada; pecíolo 5-7cm; raque 9-11 cm; folíolo $9-11 \times 4,0-6,5 \mathrm{~cm}$, suboposto a alterno, forma variável, predominantemente elíptico, base obtusa, ápice obtuso a acuminado, discolor, face adaxial verde escuro e glabra, face abaxial verde claro e pubérula; folíolos basais geralmente menores; venação broquidódroma. Cimeira escorpióide 5,5-8,5cm, axilar, laxa; bráctea e bractéola persistentes. Flor $0,4-0,5 \mathrm{~cm}$; pedicelo 1,0-1,5mm; cálice pubescente externamente, glabro internamente; tubo calicino $1,0-1,5 \mathrm{~mm}$, lacínios superiores $0,8-1,0 \mathrm{~mm}$; lacínios laterais $0,5-0,7 \mathrm{~mm}$; lacínio mediano 1,3-1,4mm; corola creme-esverdeada; vexilo 4,0-4,5mm, obovado; alas 3,5-4,0mm, oblongas; pétalas da carena semelhantes às alas; estames monadelfos 10 ; ovário estipitado, estípite $0,5-0,8 \mathrm{~mm}$, ciliado nas margens ventral e dorsal; estilete quase reto, glabro. Sâmara 6,0-8,5cm, estípite 6-10 mm; elíptico-oblonga, plana, cartácea, lisa, glabra, amarelo-esverdeada quando madura; monospérmica.

Material examinado: BRASIL. Minas Gerais: Marliéria, PERD, trilha da Lagoa do Meio, VI/1998 (fr.), Bortoluzzi et al. 176 (VIC, PERD); estrada que corta o parque, XI/1998 (fr.), Bortoluzzi et al. 402 (VIC, PERD); Viçosa, E.S.A.U., XII/1934 (fl.), Kuhlmann s.n. (VIC 1574).

Dalbergia frutescens é muito polimorfa quanto ao hábito e ao tamanho e forma dos folíolos (Almeida 1953; Carvalho 1997). No PERD esta espécie caracteriza-se por apresentar o hábito arbustivo-escandente, folíolos predominantemente elípticos, com ápice obtuso a acuminado e sâmaras amarelo-esverdeadas e monospérmicas (Fig. 11). Estas características a distinguem de $D$. foliolosa e D. nigra, ambas arbóreas com folíolos oblongos, sendo as sâmaras da primeira castanho-alaranjadas e com tricomas de base dilatada e sâmaras castanho-escuras a vináceas e glabras na última. D. frutescens ocorre nas margens de trilhas e interior de mata. É amplamente distribuída em países da América do Sul como Guiana, Venezuela, Paraguai, Bolívia, norte da Argentina e Brasil (Almeida 1953; Carvalho 1997).

1.3. Dalbergia nigra (Vell.) Allemão ex Benth., J. Linn. Soc. 4 (Suppl.): 36.1860.

Pterocarpus niger Vell., Fl. Flum.: 300. 1829.

Fig. 13-14.

Nomes populares no PERD: jacarandá-caviúna, caviúna.

Árvore ca. 12-20m alt. Ramo glabrescente, lenticelado. Folha 13-21-foliolada; pecíolo 0,7-1,5cm; raque 4,2-8,5cm; folíolo 1,2-2,5×0,4-1,4cm, alterno, oblongo, base obtusa, ápice obtuso a retuso, discolor, face adaxial verde e abaxial amarronzada, ambas as faces glabrescentes; venação broquidódroma. Cimeira escorpióide, axilar ou extra-axilar, inserida nos ramos mais velhos, geralmente intercalada com folhas menores; bráctea e bractéola caducas. Flor $0,9-1,0 \mathrm{~cm}$; pedicelo 1-2mm; cálice pubescente externamente na região dos lacínios, glabro internamente; tubo calicino 1,0-1,5mm, lacínios superiores e laterais semelhantes no tamanho 1,7-1,9mm; lacínio mediano 2,8-3,0mm; corola creme; vexilo $7-8 \times 3-4 \mathrm{~mm}$, obovado; alas $7,0-7,5 \mathrm{~mm}$ com ornamentos na base (região ventral), oblongas, curvadas; pétalas da carena semelhantes às alas; estames 

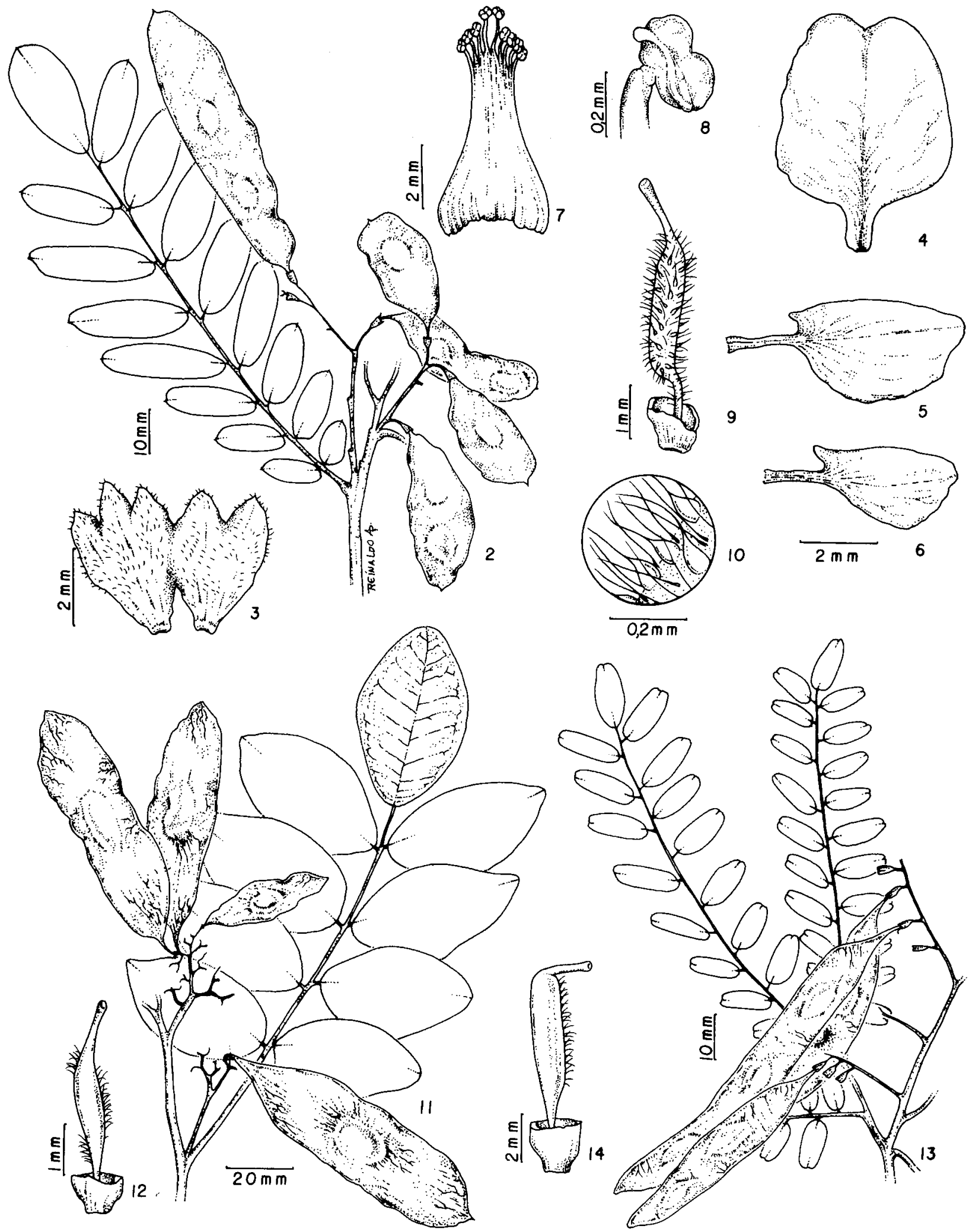

Figuras 2-10. Dalbergia foliolosa. 2. Ramo com frutos (Bortoluzzi et al. 43). 3. Cálice. 4. Vexilo. 5. Ala. 6. Pétala da carena. 7. Androceu. 8. detalhe da antera com deiscência transversal. 9. Cálice e gineceu. 10. Detalhe dos tricomas glandulares com base dilatada presentes no ovário (Lopes \& Silva 527). Figuras 11-12. Dalbergia frutescens. 11. Ramo com frutos (Bortoluzzi et al. 176). 12. Cálice e gineceu (ovário com ambas as margens ciliadas e estilete quase reto) (Kuhlmann s.n. VIC 1574). Figuras 13-14. Dalbergia nigra. 13. Ramo com frutos. 14. Cálice e gineceu (ovário com uma das margem ciliada e estilete geniculado) (Bortoluzzi et al. 120 VIC e Adriano s.n. PERD 173). 
monadelfos 10; ovário estipitado, estípite 2-3mm, glabro, ciliado na margem ventral; estilete geniculado (perpendicular ao ovário). Sâmara 4,5-6,0×0,9-1,5cm, estípite $0,3-0,8 \mathrm{~mm}$, elíptica, plana, cartácea, glabra, castanho-escura a vinácea; mono ou dispérmica, raramente com 3 sementes.

Material examinado: BRASIL. Minas Gerais: Marliéria, PERD, local não-determinado, X/1996 (fl.) Adriano s.n. (PERD 173); trilha da Lagoa do Meio, IV/1998 (fr.), Bortoluzzi et al. 120 (VIC).

Dalbergia nigra caracteriza-se pelos folíolos oblongos com ápice obtuso, às vezes retuso, ovário glabro, exceto na margem ventral, onde é ciliado; estilete geniculado (Fig. 14) e sâmaras glabras (Fig. 13), cartáceas, castanho-escuras a vináceas. D. nigra está bem representada no PERD, ocorrendo em todas as trilhas estudadas e no interior de mata. Ocorre do sul da Bahia até o norte do Espírito Santo, Minas Gerais e norte de São Paulo (Carvalho 1997).

2. Erythrina L., Sp. Pl.: 216. 1737.

Árvore ou arbusto, armado ou inerme. Folha trifoliolada; estípula caduca; estipela persistente. Racemo ou pseudo-racemo com flores fasciculadas, 2 ou mais, inseridas diretamente no eixo de primeira ordem, axilar ou terminal; bráctea e bractéola persistentes ou caducas. Cálice campanulado a tubular, assimétrico, geralmente calcarado ou caloso no lado carenal e/ou vexilar, às vezes 5-laciniado, lacínios geralmente truncados ou reduzidos; corola vermelha, vermelhorosada ou laranja-avermelhada; vexilo elíptico a lanceolado, curto-ungüiculado; alas oblongas a elípticas, reduzidas em relação à carena e ao vexilo; pétalas da carena fundidas no dorso, levemente menores que o vexilo; estames monadelfos ou diadelfos, anteras elípticas, deiscência longitudinal; ovário estipitado; estilete terminal, curvado; estigma terminal. Legume ou folículo, linear-oblongo, compresso ou cilíndrico, curvo ou reto, deiscente em uma ou ambas as margens; mono ou polispérmico.

2.1. Erythrina speciosa Andr., Bot. Repos. 7: 443. 1806. Fig. 15-17.

Árvore ca. 3-4m alt. Tronco aculeado, ramo glabrescente, lenticelado, aculeado. Folha caduca no período reprodutivo; estípula caduca; estipela glanduliforme; pecíolo 6-9,7,0cm, raque $1-3 \mathrm{~cm}$, pecíolo, raque e nervura mediana dos folíolos com acúleos; folíolos laterais assimétricos, folíolo terminal 6,2-12×8,0-10,4cm, ovado a romboidal, base obtusa a subtruncada, ápice agudo, concolor, ambas as faces velutinas; venação broquidódroma. Racemo $18-21 \mathrm{~cm}$, terminal; bráctea e bractéola persistente. Flor 5,2-7cm; pedicelo 3-5mm, viloso; cálice campanulado, calcarado no lado carenal, velutino externamente e glabro internamente; tubo calicino $10-12 \mathrm{~mm}$, corola vermelha; vexilo $50-70 \times 10-14 \mathrm{~mm}$, estreitamente elíptico; alas 6-11×10-25mm, oblongas a elípticas, menores que a carena; pétalas da carena $19-31 \times 5-7 \mathrm{~mm}$, oblongas; estames diadelfos 9+1; ovário estipitado, estípite 5-6mm, viloso; estilete levemente curvado, glabro. Legume 17,5-19,0×1,1-1,2cm, estípite 15-20mm, oblongo, valvas cartáceas; polispérmico.

Material examinado: BRASIL. Minas Gerais: Marliéria, PERD: estrada que corta o parque, próximo ao Salão Dourado, área limítrofe ao parque, VIII/1999 (fl., fr.), Bortoluzzi et al. 706 (VIC).

Erythrina speciosa caracteriza-se pela presença de acúleos no tronco, dorso do pecíolo, raque e na nervura mediana dos folíolos (Fig. 15-16), pelas inflorescências em racemos terminais (Fig. 17); corola vermelha com o vexilo estreitamente elíptico, cerca de cinco vezes mais longo do que largo e fruto tipo legume. Esses caracteres separam E. speciosa de E. verna, esta última geralmente com acúleos presentes apenas no tronco; inflorescências em pseudo-racemos axilares; corola laranja-avermelhada com o vexilo amplo-elíptico cerca de 1,5 vez mais longo do que largo e fruto tipo folículo. Ambas as espécies apresentam-se totalmente destituídas de folhas no período reprodutivo. No PERD, E. speciosa ocorre em área brejosa. Distribui-se pela América do Sul; no Brasil é encontrada naturalmente nas Regiões Sudeste e Sul chegando até Santa Catarina (Krukoff \& Barneby 1974; Lorenzi 1992; Lima 1995).

\subsection{Erythrina verna Vell., Fl. Flum. 7: 304. 1825.}

Fig. 18-20.

Árvore ca. 15-20m alt. Tronco aculeado, ramo glabrescente, lenticelado, aculeado. Folha caduca no período reprodutivo; estípula caduca; estipela glanduliforme; pecíolo $6,8-13 \mathrm{~cm}$; raque $3-9 \mathrm{~cm}$; pecíolo, raque e nervuras sem acúleos; folíolos laterais assimétricos, folíolo terminal $13-20 \times 12,0-15,5 \mathrm{~cm}$, amploelíptico ou oval, base obtusa a levemente cuneada, ápice agudo a acuminado, concolor, face adaxial glabrescente; face abaxial tomentosa; venação broquidódroma. Pseudo-racemo 10-20 cm, axilar; bráctea e bractéola caducas. Flor 2,0-4,5cm; pedicelo $15-35 \mathrm{~mm}$; cálice campanulado, tomentoso externamente e glabro internamente, persistente no fruto; tubo calicino $4-6 \mathrm{~mm}$; 
corola laranja-avermelhada; vexilo $26-45 \times 17-30 \mathrm{~mm}$, amplo-elíptico; alas 9-13×5mm, oblongas, menores que a carena; pétalas da carena $27-30 \times 10-12 \mathrm{~mm}$, falcadas; estames diadelfos, 9+1; ovário estipitado, estípite 0,5-0,7mm, tomentoso; estilete levemente curvado, glabro. Folículo $11,0-15,5 \times 1,3-1,5 \mathrm{~cm}$, estípite $20-23 \mathrm{~mm}$, papiráceo, brilhante internamente, glabrescente, castanho-escuro; polispérmico.

Material examinado: BRASIL. Minas Gerais: Marliéria, PERD, trilha de Porto Capim, IX/1997 (fr.), Lopes 386 (VIC); trilha do Aníbal, VIII/1998 (fl.), Bortoluzzi et al. 224 (VIC, PERD).

Erythrina verna caracteriza-se pelas inflorescências em pseudo-racemos axilares, corola laranjaavermelhada e fruto tipo folículo. Ocorre no interior de mata e às margens de trilhas, geralmente sobre substrato seco. É nativa da América do Sul, podendo ser encontrada no leste da Bolívia e no Brasil (Krukoff \& Barneby 1974).

3. Lonchocarpus Kunth, Nov. Gen. Sp. (folio ed.) 6: 300. 1824.

Árvore ou arbusto escandente a liana. Folha imparipinada, plurifoliolada, alterno-espiralada; folíolos opostos; estípula geralmente caduca; estipela geralmente ausente. Pseudo-racemo simples, fasciculado ou ramificado, ou panícula, axilar e/ou terminal, às vezes em ramos áfilos; flores solitárias, geminadas ou fasciculadas agrupadas em braquiblastos cilíndricos e lenhosos; bráctea e bractéola freqüentemente caducas. Cálice campanulado, lacínios ou lobos 5 , variadamente fundidos; corola branca, violácea a purpúrea; vexilo orbicular, oblongo a oboval, geralmente ungüiculado e piloso no dorso; alas oblongas, semi-obovais, levemente aderidas à carena, ungüiculadas; pétalas da carena de tamanho semelhante às alas, fundidas no dorso, raramente livres; estames pseudomonadelfos, anteras oblongas, deiscência longitudinal; ovário séssil ou estipitado; estilete reto ou curvado, piloso ou glabro; estigma terminal. Legume suborbicular, oblongo ou alongado, geralmente compresso, membranáceo a subcoriáceo, raramente lenhoso, indeiscente ou deiscente; geralmente polispérmico.

3.1. Lonchocarpus costatus Benth., J. Linn. Soc. 4 (Suppl.): 100. 1860.

Fig. 21.

Árvore ca. 3-8m alt. Ramo glabrescente, lenticelado. Folha 9-11-foliolada; pecíolo 4,5-8,0cm; raque $8-14 \mathrm{~cm}$; estipela linear, persistente; folíolo 8,5-9,5×3,2-3,5cm, oposto, elíptico a oblongo, base obtusa, ápice acuminado, discolor, face adaxial brilhante, esparso-pubérula, face abaxial opaca pubescente a vilosa; venação broquidódroma, fortemente proeminente na face abaxial. Pseudo-racemo $30-50 \mathrm{~cm}$, densifloro, congesto, axilar, terminal ou em ramo áfilo, fasciculado ou não, flores inseridas em braquiblastos cilíndricos e lenhosos; bráctea e bractéola caducas. Flor 0,9-1,0cm; pedicelo 1,0-3,5mm; cálice tomentoso externamente, glabro internamente, tubo calicino ca. $3 \mathrm{~mm}$, todos os lobos subtruncados, menores que $1 \mathrm{~mm}$; corola violácea; vexilo $10-11 \times 0,8-10 \mathrm{~mm}$, oblongo-obovado, caloso na base; alas 11-12×2-3mm, oblongas, esparso-seríceas na nervura mediana; pétalas da carena semi-obovais, curvadas, seríceas no ápice com tamanho semelhante às alas; estames pseudomonadelfos 10; ovário séssil, viloso; estilete reto, pubérulo. Legume 6,5-10 $\times$ 2,5-2,8cm, séssil, oblongo, plano, lenhoso, tomentoso a pubérulo, castanho-escuro; polispérmico.

Material examinado: BRASIL. Minas Gerais: Marliéria, PERD, Ponte Queimada, II/1999 (fl., fr.), Bortoluzzi et al. 498 (VIC, PERD); V/1999 (fr.), Bortoluzzi et al. 653 (VIC).

Folíolos opostos e estipelados, com a venação fortemente proeminente na face abaxial; pseudo-racemo densifloro e congesto; corola violácea e frutos planos e lenhosos (Fig. 21) caracterizam Lonchocarpus costatus. Tozzi (1989) apresentou uma proposta de nova combinação sobre $L$. costatus transferindo esse binômio para o gênero Deguelia; embora o novo binômio não tenha sido validamente publicado, foi utilizado nas obras de Lorenzi (1992) e Mendonça Filho (1996). L. costatus (sob Deguelia) ocorre nos Estados de Minas Gerais, Espírito Santo e Rio de Janeiro (Tozzi 1989).

\section{Machaerium Pers., Syn. Pl. 2: 276. 1807.}

Árvore ou arbusto escandente, armada ou inerme. Folha imparipinada; estípula espinescente ou não, caduca ou persistente; sem estipela. Racemo fasciculado ou panícula, axilar ou terminal; bráctea comumente caduca; bractéola persistente. Cálice campanulado, raramente tubuloso, 5-laciniado, lacínios superiores 2, parcialmente unidos, lacínios inferiores 3 , desiguais, sendo o mediano maior que os laterais; corola branca, creme-esverdeada, lilás ou violácea; vexilo ovado ou orbicular, curtoungüiculado; piloso no dorso; alas oblongas, falcadas, ungüiculadas; pétalas da carena curvadas, fundidas dorsalmente, semelhantes às alas ou menores; estames mono ou diadelfos, filetes glabros ou pilosos, anteras geralmente oblongas, deiscência longitudinal; ovário 


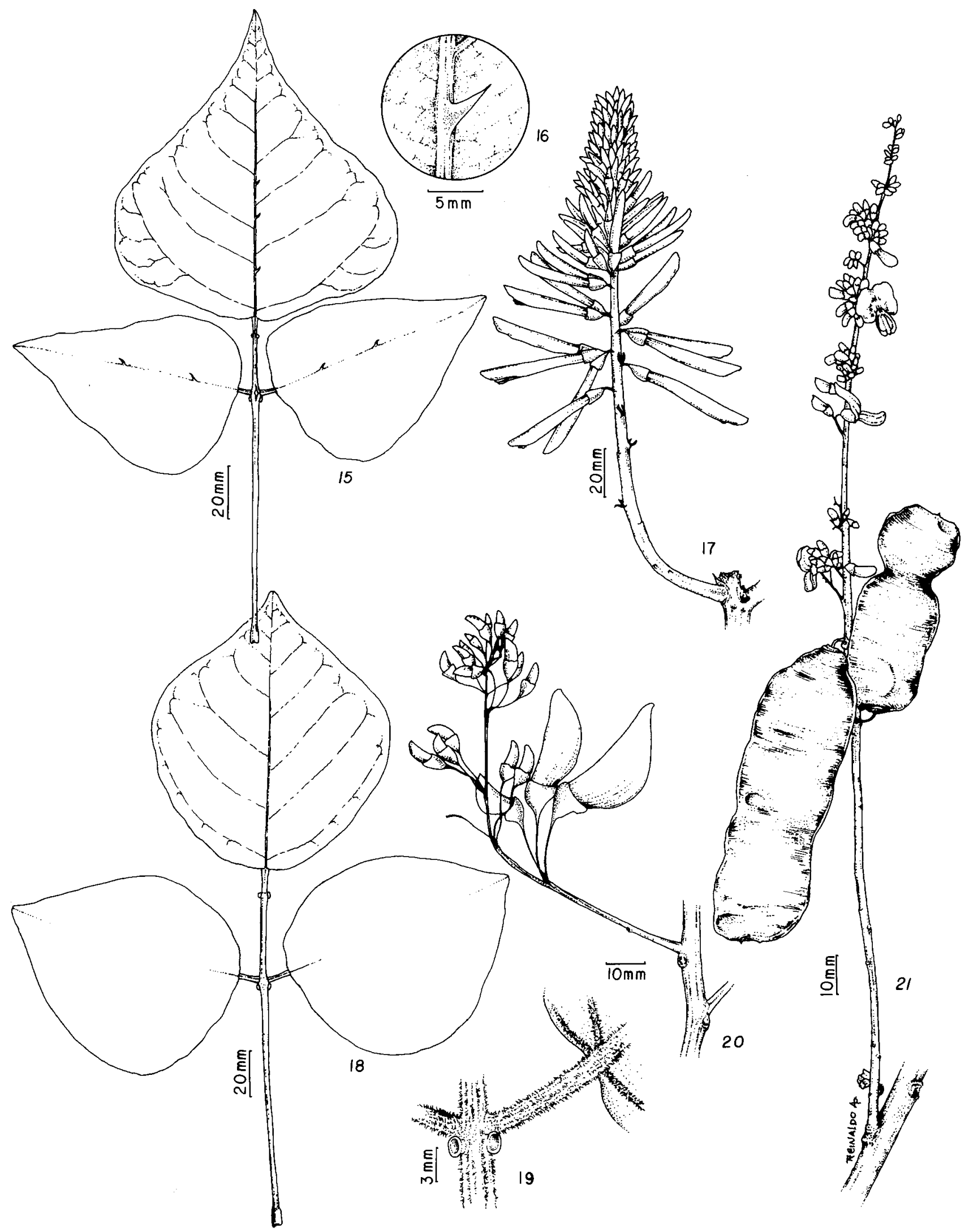

Figuras 15-17. Erythrina speciosa. 15. Folha com acúleos na nervura mediana dos folíolos. 16. Detalhe do acúleo na nervura mediana do folíolo. 17. Inflorescência (Bortoluzzi et al. 706). Figuras 18-20. Erythrina verna. 18. Folha. 19. Detalhe das estipelas glanduliformes. 20. Inflorescência (Bortoluzzi et al. 224). Figura 21. Lonchocarpus costatus. 21. Ramo com flores e frutos (Bortoluzzi et al. 498). 
estipitado; estilete reto ou curvado; estigma terminal. Sâmara geralmente cultriforme ou falciforme, incurvada ou não na região do núcleo seminífero; região do núcleo seminífero basal, asa membranácea, geralmente reticulada; monospérmica.

4.1. Machaerium aculeatum Raddi, Mem. Mat. Fis. Soc. Ital. Sci. Modena, Pt. Mem. Fis. 18: 398. 1820.

Fig. 22-24.

Arbusto escandente. Ramo pubérulo a glabrescente, lenticelado, armado; estípula espinescente unciforme. Folha 26-38-foliolada; pecíolo $0,5-0,8 \mathrm{~cm}$; raque 9,5-11 cm; folíolo 1,0-1,5×0,5-0,7cm, oblongo, suboposto a alterno, base obtusa, ápice retuso, concolor, face adaxial glabrescente, face abaxial esparso-pubérula na nervura mediana; venação craspedódroma. Panícula $5,5-13 \mathrm{~cm}$, axilar e terminal; bractéolas obovadas. Flor 1,0-1,5cm; pedicelo 1,5-2,0mm; cálice campanulado, pubescente externamente, glabro internamente; tubo calicino 4-5mm, lacínios superiores, laterais e mediano semelhantes no tamanho, ca. $1 \mathrm{~mm}$; corola violácea; vexilo ca. $8 \times 5 \mathrm{~mm}$, suborbicular, emarginado; alas 7,0-7,5 $\times 2 \mathrm{~mm}$, oblongas; pétalas da carena 4,5-5× $1-2 \mathrm{~mm}$, levemente fundidas no dorso, mais tarde livres; estames diadelfos $5+5$, filetes glabros; ovário estipitado, estípite 1-2mm, pubérulo a tomentoso; estilete curvado, glabro. Sâmara 5,0-5,7×0,7-1,0cm, estípite 5-8mm, cultriforme, incurvada na região do núcleo seminífero, tomentosa, base e ápice obtusos; região do núcleo seminífero 1,0-1,5cm larg., enegrecida, asa 2,0-2,5cm larg., reticulada, avermelhada quando jovem, castanhoescura quando madura.

Material examinado: BRASIL. Minas Gerais: Marliéria, PERD, estrada que corta o Parque, IV/1999 (fr.), Bortoluzzi et al. 615 (VIC, PERD); margem da Lagoa Porto Capim, V/1999 (fr.), Bortoluzzi et al. 640 (VIC, PERD).

Machaerium aculeatum caracteriza-se pelo hábito arbustivo-escandente, ramos com estípulas espinescentes unciformes (Fig. 23) e folhas com 26-38 folíolos oblongos e ápice retuso (Fig. 22). No PERD, esta espécie assemelha-se à $M$. caratinganum na forma das estípulas, mas esta difere pelo número e pela forma dos folíolos, apresentando folhas com 5-9 folíolos ovados a elípticos com ápices agudos a acuminados, além das sâmaras maiores $6,5-8,5 \mathrm{~cm}$. Outra espécie muito próxima de $M$. aculeatum é $M$. hirtum, discutida posteriormente na referida espécie. No Brasil ocorre nos Estados de São Paulo, Rio de Janeiro e Minas Gerais, sendo referida também para Bolívia e Argentina (Hoehne 1941).
4.2. Machaerium caratinganum Kuhlm. \& Hoehne, Arq. Bot. Estado São Paulo 1: 30. 1938.

Fig. 27-29.

Arbusto escandente. Ramo glabrescente, lenticelado, fortemente armado; estípula aculeada, unciforme. Folha 5-9-foliolada; folíolo 9,5-10×3,5-4,7cm, ovado a elíptico, base cordada a obtusa ou atenuada no folíolo terminal, ápice agudo a acuminado, às vezes emarginado, concolor, glabro ou pubérulo na nervura mediana em ambas as faces; venação craspedódroma (nervura de $2^{\mathrm{a}}$ ordem se ramifica muito pouco), folíolos basais menores. Racemo, às vezes em panícula, $2-5 \mathrm{~cm}$; bráctea persistente; bractéola ovada, persistente. Flor 0,7-0,8cm; séssil; cálice 0,3-0,5mm, campanulado, pubérulo externamente, glabro internamente, lacínios superiores, laterais e mediano semelhantes no tamanho, menores que $1 \mathrm{~mm}$; corola violácea; vexilo ca. 7-8mm, suborbicular; alas oblongas a subfalcadas; pétalas da carena de tamanho semelhantes às alas e ao vexilo, glabras; estames diadelfos 9+1, filetes glabros; ovário estipitado, pubérulo; estilete reto, glabro. Sâmara $6,5-8,5 \mathrm{~cm}$, estípite $10-20 \mathrm{~mm}$, falciforme, incurvada na região do núcleo seminífero, base e ápice obtusos, glabra, região do núcleo seminífero 0,6-1,0cm larg., enegrecida; asa 1,0-1,5cm larg., oblonga, reticulada, amareloesverdeada quando jovem e castanha quando madura.

Material examinado: BRASIL. Minas Gerais: Marliéria, PERD, trilha do Aníbal, VI/1998 (fr.), Bortoluzzi et al. 169 (VIC).

Os ramos fortemente armados e folhas com 5-9 folíolos, ovados a elípticos com ápice agudo a acuminados (Fig. 27) caracterizam M. caratinganum. Das espécies de Machaerium estudadas no PERD, $M$. caratinganum e $M$. aculeatum foram as únicas que apresentaram estípulas espinescentes unciformes (Fig. 23 e 28). M. caratinganum ocorre às margens de trilhas e interior de mata, em local sombreado. É citada para o Estado de Minas Gerais e para a Região Sul do Brasil por Hoehne (1941) e Mendonça Filho (1996).

4.3. Machaerium fulvovenosum $\mathrm{H}$. C. Lima, Bradea 3: 45.1983.

Fig. 30-33.

Árvore ca. 4-10m alt. Ramo tomentoso a glabrescente, lenticelado. Folha 9-13-foliolada; pecíolo 2,5-2,8cm; raque $8-18 \mathrm{~cm}$; estípula oblongo-lanceolada, estriada, persistente; folíolo 6,2-7,3×2,4-3,0cm, alterno, elíptico, ovado a obovado, base obtusa a atenuada, ápice obtuso a agudo, concolor, face adaxial glabrecente com 

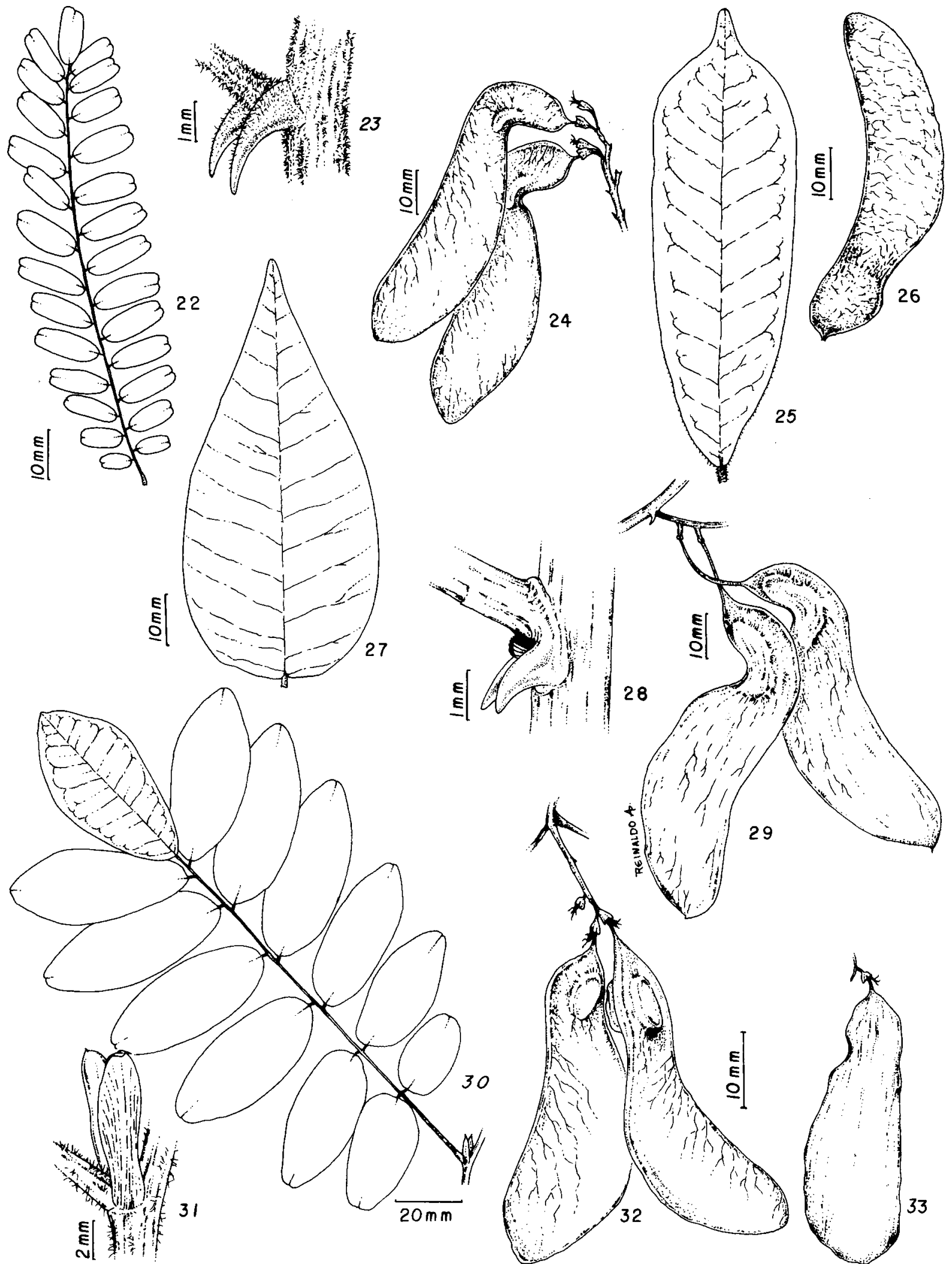
nervuras primária e secundárias tomentosas, face abaxial tomentosa; folíolos basais menores; venação broquidódroma, proeminente na face abaxial. Panícula 7-17cm, laxa, axilar e terminal; bráctea caduca; bractéola suborbicular. Flor 1,0-1,3cm, séssil; cálice campanulado, tomentoso externamente, tubo calicino 2-3mm, todos os lacínios semelhantes no tamanho ca. $1 \mathrm{~mm}$; corola violácea; vexilo 8-9×7-9mm, suborbicular; alas e carena oblongas, subfalcadas com tamanho semelhantes ao vexilo; estames diadelfos $9+1$, filetes pilosos; ovário estipitado, estípite ca. 2-3mm, pubérulo; estilete curvado, glabro. Sâmara 6-8cm, estípite 7-15mm, cultriforme, não incurvada na região do núcleo seminífero, tomentosa a glabrescente, ápice e base obtusos; região do núcleo seminífero ca. $1 \mathrm{~cm}$ larg., intumescida e proeminente, estriada; asa $1-1,5 \mathrm{~cm}$ larg., oblonga, reticulada, castanha quando madura.

Material examinado: BRASIL. Minas Gerais: Marliéria, PERD, trilha do Aníbal, II/1998 (fr.), Bovini et al. 1294 (VIC); VIII/1998 (fr.), Bortoluzzi et al. 205 (VIC); VIII/1998 (fr.), Bortoluzzi et al. 206 (VIC, PERD); Ponte Queimada, I/1999 (fr.), Bortoluzzi et al. 471 (VIC, PERD); Viçosa, E.S.A.V., 22/II/1936 (fl.), Kuhlmann s.n. (VIC 1326).

Machaerium fulvovenosum caracteriza-se pelos folíolos com a face adaxial glabrescente, nervuras primária e secundárias tomentosas e face abaxial tomentosa; sâmara com a região do núcleo seminífero estriada, intumescida e proeminente (Fig. 32), sendo oportuno ressaltar que, quando coletadas imaturas, estas sâmaras apresentam a região do núcleo seminífero lisa (Fig. 33), não intumescida e proeminente. Embora o material coletado no PERD tenha sido identificado como M. fulvovenosum é importante ressaltar que a planta possui as estípulas oblongo-lanceoladas, estriadas e persistentes na fase de frutificação (Fig. 31), característica não observada no material de $M$. fulvovenosum, examinado para o Estado do Espírito Santo, onde Lima (1983), não observou a presença de estípulas, referindo-as como caducas. O espécime utilizado para a descrição da flor foi Machaerium fruticosum (Vell.) Hoehne sensu Hoehne (1941). M. fulvovenosum ocorre em Minas Gerais (Hoehne 1941), Espírito Santo (Lima 1983), sul da Bahia e em alguns trechos de florestas do vale do Rio Doce (Haroldo Cavalcante Lima 2002, com. pess.).

4.4. Machaerium hirtum (Vell.) Stellfeld, Tribuna Farm. 14 (12): 246. 1946.

Nissolia hirta Vell., Fl. Flum. 296. 1829 [1825].
Machaerium angustifolium Vogel, Linnaea 11: 193. 1837. Fig. 34-36.

Nome popular no PERD: angico-roxo.

Árvore ca. 4-6m alt. Tronco quando injuriado com exsudato avermelhado, ramo glabrescente, lenticelado, armado; estípula espinescente, retilínea. Folha 19-53-foliolada; pecíolo $0,4-1 \mathrm{~cm}$; raque $6,5-13,5 \mathrm{~cm}$; folíolo 0,8-2,0×0,3-0,5cm, estreito-oblongo, suboposto ou alterno, base assimétrica, ápice retuso, mucronado, concolor; venação craspedódroma. Panícula $6,0-9,5 \mathrm{~cm}$, laxa, terminal e axilar; bráctea caduca; bractéola orbicular, persistente. Flor 1,0-1,5cm, pedicelo ca. $2 \mathrm{~mm}$; cálice tubuloso esparso-tomentoso externamente, glabro internamente, tubo calicino 4-5mm, lacínios superiores, laterais e mediano semelhantes no tamanho, 1-2mm; corola violácea; vexilo $8,0-13 \times 4-5 \mathrm{~mm}$, oblongo, reflexo, com mancha creme na parte central; alas $10-12 \mathrm{~mm}$, elíptico-oblongas, curvadas, seríceas no dorso; pétalas da carena de forma e tamanho semelhantes às alas, às vezes esbranquiçadas; estames monadelfos 10 ou diadelfos $5+5$, filetes glabros; ovário estipitado, estípite 2-6mm, incano-velutino; estilete levemente curvado. Sâmara 5,0-6,5cm, estípite 10-20mm, cultriforme, não incurvada na região do núcleo seminífero, esparsotomentosa, ápice obtuso a agudo, mucronado; região do núcleo seminífero $0,7-1,0 \mathrm{~cm}$ larg., enegrecida; asa 1,2-1,4cm larg., castanha quando madura.

Material examinado: BRASIL. Minas Gerais: Marliéria, PERD, estrada que corta o Parque, II/1999 (fl.), Bortoluzzi et al. 509 (VIC, PERD); III/1999 (fr.), Bortoluzzi et al. 574 (VIC, PERD)

O porte arbóreo, ramos com estípulas espinescentes retilíneas (Fig. 34), folhas com 19 a 53 folíolos e folíolos estreito-oblongos caracterizam Machaerium hirtum. Lima (1995) tratou M. angustifolium Vogel como sinônimo dessa espécie. De acordo com Hoehne (1941), $M$. angustifolium estava como sinônimo de $M$. aculeatum, espécie muito próxima de $M$. hirtum. Recentemente, Mendonça Filho et al. (2002) confirmaram a separação de $M$. aculeatum e $M$. hirtum, com base em números cromossômicos e caracteres morfológicos. Ambas as espécies ocorrem no PERD, podendo ser diferenciadas principalmente pelo porte arbóreo e pelos ramos com estípulas espinescentes retilíneas em $M$. hirtum e pelo hábito arbustivo-escandente, pelos ramos com estípulas espinescentes unciformes (Fig. 23) e pelo número de folíolos menor variando de 26-38 em M. aculeatum. M. hirtum ocorre às margens de trilhas, estradas e Ponte Queimada, em substratos secos ou úmidos e pedregosos como nas 
margens do Rio Doce. Distribui-se pelos Estados do Rio de Janeiro, Minas Gerais e São Paulo (Lima 1995; Mendonça Filho 1996; Sartori \& Tozzi 1998).

\subsection{Machaerium oblongifolium Vogel, Linnaea 11:} 181.1837.

Fig. 37-38.

Arbusto escandente. Tronco, quando injuriado, com exsudato avermelhado, ramo glabrescente, lenticelado, inerme; estípula deltóide. Folha 5-7-foliolada; pecíolo 1,2-4,5cm; raque 1,2-8,5cm; folíolo 3,0-9,7×1,2-3,7cm, subosposto, alterno, oblongo a obovado, base obtusa, ápice obtuso a agudo, concolor, face adaxial glabra, face abaxial ferrugíneo-velutina; venação broquidódroma. Racemo ou panícula, pêndulo, axilar, $5-6 \mathrm{~cm}$; bráctea caduca; bractéola ovada, persistente. Flor $0,8-0,9 \mathrm{~cm}$; cálice campanulado, externamente tomentoso, internamente glabro, tubo calicino ca. $3 \mathrm{~mm}$, lacínios superiores, laterais e mediano semelhantes no tamanho, ca. $1 \mathrm{~mm}$; corola branca; vexilo ca. $8 \mathrm{~mm}$, orbicular, ungüiculado, seríceo externamente; alas $7-8 \mathrm{~mm}$, oblongas, seríceas na base da ungüícula; pétalas da carena semelhantes às alas; estames monadelfos 10 ; ovário estipitado, estípite 1,5-2,0mm, viloso; estilete reto, glabro. Sâmara 4,8-6,0cm, estípite 3-6mm, cultriforme, não incurvada na região do núcleo seminífero, glabra, base obtusa, ápice obtuso ou agudo; região do núcleo seminífero 1,0-1,2cm larg., espessada, enegrecida; asa 1,0-1,5cm larg., reticulada, castanha.

Material examinado: BRASIL. Minas Gerais: Marliéria, PERD, trilha da Mombaça, IV/1998, Bortoluzzi et al. 99 (VIC); trilha da Lagoa do Meio, VI/1998 (fr.), Bortoluzzi et al. 180 (VIC, PERD); trilha do Aníbal, VIII/1998 (fr.), Bortoluzzi et al. 216 (VIC, PERD). São Paulo: Parque do Estado de São Paulo, XI/1944, Hoehne s.n. (fl.), (UEC 79073).

As folhas com 5-7 folíolos oblongos a obovados, ápice geralmente obtuso ou curto-acuminado com a face adaxial glabra e abaxial ferrugíneo-velutina e sâmara oblonga foram os caracteres utilizados no reconhecimento de $M$. oblongifolium. Assim como em $M$. triste, os folíolos de M. oblongifolium, embora predominantemente oblongos, apresentaram variação no tamanho e na forma, inclusive no mesmo indivíduo. Além das folhas, os frutos também variaram quanto à forma e tipo de ápice. M. oblongifolium ocorre às margens de trilhas, estrada e lagoa. Distribui-se na Bahia, Espirito Santo, Paraná e Rio de Janeiro (Lima et al. 1994), Minas Gerais (Mendonça Filho 1996) e São Paulo (Sartori \& Tozzi 1998).
4.6. Machaerium stipitatum Vogel, Linnaea 11: 189. 1837.

Fig. 39.

Árvore ca. $4 \mathrm{~m}$ alt. Ramo glabrescente, lenticelado, inerme. Folha 19-25 foliolada; estípulas caducas; pecíolo 1,7-2,0cm; raque 12,0-17,5cm; folíolo 5,0-6,1×1,3-1,7cm, alterno, elíptico, base obtusa às vezes atenuada, ápice obtuso a retuso, mucronado, concolor, face adaxial glabra, face abaxial serícea; venação broquidódroma. Panícula terminal e axilar, 5-6cm; bractéola oblonga, persistente. Flor $0,5-0,6 \mathrm{~cm}$; cálice campanulado, esparso-tomentoso, glabro internamente, tubo calicino 1,8-2,0mm, lacínios superiores, laterais e mediano de tamanhos semelhantes ca. $1 \mathrm{~mm}$; corola creme ou esverdeada; vexilo 4-5×2-3 mm, obovado; alas 4-5mm, oblongas; pétalas da carena semelhantes às alas; estames monadelfos 10, filetes glabros; ovário estipitado, estípite 2,5-3,0mm, viloso no ápice; estilete reto, glabro. Sâmara 4,8-6,0cm, longo-estipitada, estípite 5-11mm, falciforme, não incurvada na região do núcleo seminífero, glabra, base e ápice obtusos; região do núcleo seminífero 1,0-1,5cm larg., enegrecida; asa 1,0-1,5cm larg., reticulada, castanho-amarelada.

Material examinado: BRASIL. Minas Gerais: Marliéria, PERD, estrada que corta o parque, IV/1999 (fl.), Bortoluzzi et al. 612 (VIC); Viçosa, E.S.A.V., V/1935 (fr.), Kuhlmann s.n. (VIC 2226).

O porte arbóreo com ramificações abertas e pendentes; folhas com 19-25 folíolos e sâmaras longoestipitadas com a região do núcleo seminífero enegrecida caracterizam $M$. stipitatum. Neste trabalho foi encontrado um número de folíolos maior, em relação ao encontrado por Sartori \& Tozzi (1998) de 7-12 folíolos. Há registros dessa espécie para o Rio de Janeiro, São Paulo, Minas Gerais e Paraná (Barroso 1964; Mendonça Filho1996; Sartori \& Tozzi 1998).

4.7. Machaerium ternatum Kuhlm. \& Hoehne, Arq. Bot. Estado São Paulo 1: 35. 1938.

Fig. 40-41.

Arbusto escandente. Ramo glabrescente, lenticelado, inerme; estípula triangular-lanceolada, caduca. Folha 3-foliolada; pecíolo 5,0-8,5cm; raque 7,5-15cm; folíolo 6,8-7,7×4,3-5,0cm, alterno, amplo-elíptico, base obtusa, ápice acuminado a levemente retuso, concolor, às vezes enegrecido quando seco, glabro em ambas as faces; venação broquidódroma. Racemo ou panícula 4-11 cm, axilar; bractéola ovada, persistente. Flor 6-8mm, séssil; cálice campanulado, lacínios superiores parcialmente unidos, lacínios inferiores desiguais, o 

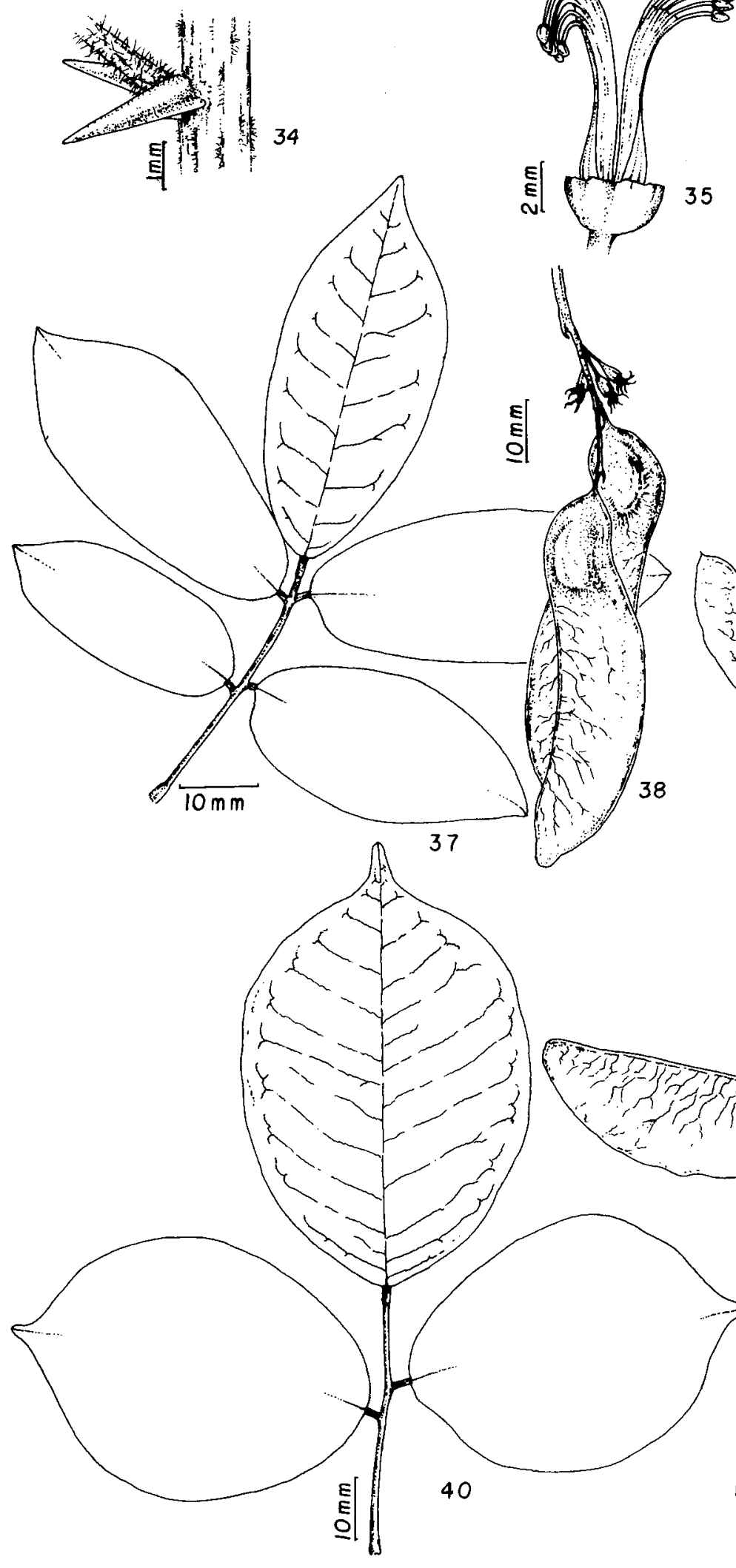
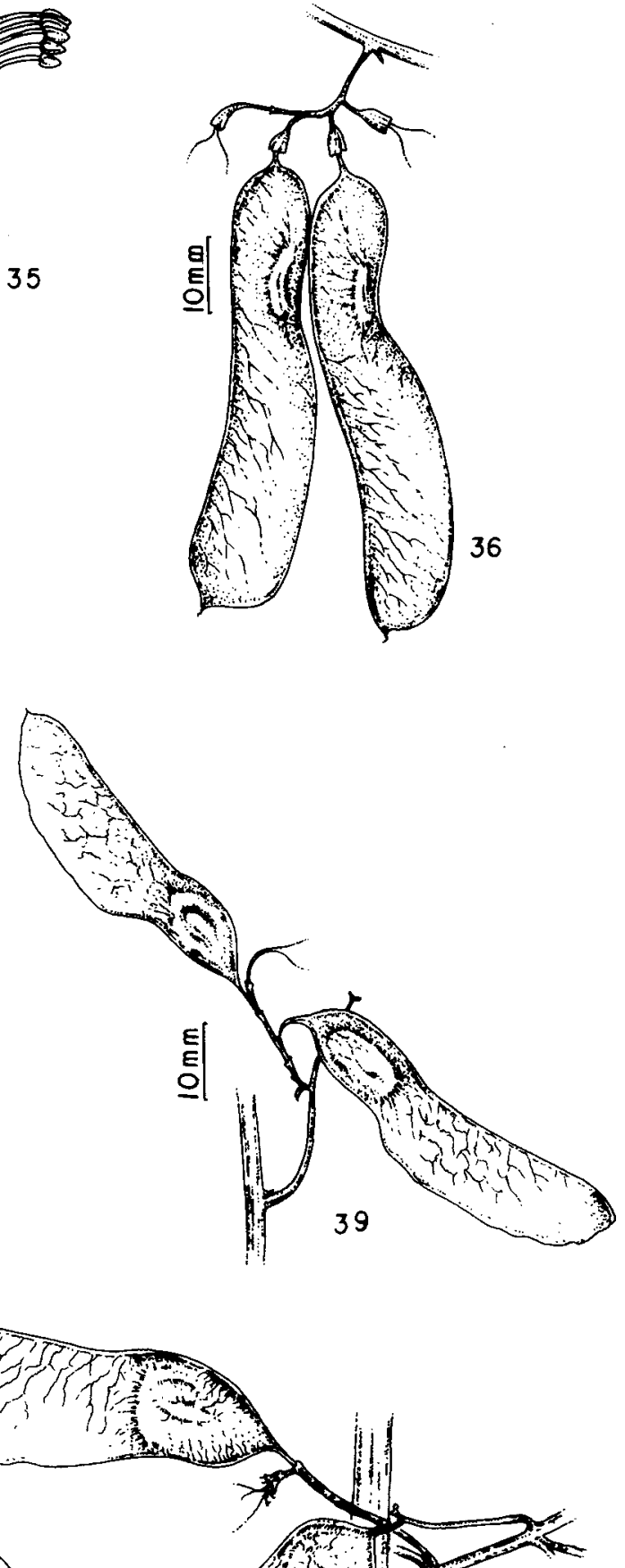

Figuras 34-36. Machaerium hirtum. 34. Estípulas espinescentes retilíneas. 35. Androceu. 36. Frutos (Bortoluzzi et al. 522 e 574$)$. Figuras 37-38. Machaerium oblongifolium. 37. Folha. 38. Frutos (Bortoluzzi et al. 216). Figura 39. Machaerium stipitatum. 39. Frutos (Mexia s.n. VIC 3179). Figuras 40-41. Machaerium ternatum. 40. Folha. 41. Frutos (Bortoluzzi et al. 200). 
mediano maior que os laterais; vexilo ca. $7 \mathrm{~mm}$, obovado; alas $6-7 \mathrm{~mm}$, oblongas, levemente falcadas; pétalas da carena ca. $6 \mathrm{~mm}$, curvadas, falcadas; estames diadelfos $9+1$, filetes glabros; ovário hirsuto. Sâmara $6-7 \mathrm{~cm}$, estípite $0,3-0,5 \mathrm{~mm}$, falciforme, não incurvada na região do núcleo seminífero, glabra, base obtusa, ápice obtuso a agudo, glabrescente; região do núcleo seminífero $1,5 \mathrm{~cm}$ larg.; asa 1,5-1,7cm larg., reticulada, castanhoescura.

Material examinado: BRASIL. Minas Gerais: Marliéria, PERD, estrada do restaurante, III/1998 (fr.), Bortoluzzi et al. 53 (VIC); trilha da Garapa Torta, VII/1998 (fr.), Bortoluzzi et al. 200 (VIC, PERD).

Machaerium ternatum é reconhecida pelo porte escandente apresentando folhas com três folíolos completamente glabros, cerca de 1,5 vez mais longos do que largos (Fig. 40). Das espécies de Machaerium estudadas no PERD, M. ternatum foi a única que apresentou folhas com três folíolos; as demais espécies do gênero possuem folhas com cinco ou mais folíolos. Na Estação Ecológica de Caratinga, Mendonça Filho (1996) observou 3-5 folíolos para essa espécie. Ocorre nos Estados do Rio de Janeiro e de Minas Gerais (Hoehne 1941; Barroso 1964; Mendonça Filho 1996).

4.8. Machaerium triste Vogel, Linnaea 11: 416. 1837. Fig. 25-26.

Arbusto escandente. Ramo pubescente a tomentoso, lenticelado, inerme; estípula caduca. Folha 7-9-foliolada; pecíolo $2,5-2,8 \mathrm{~cm}$, raque $8-15 \mathrm{~cm}$; folíolo $7,0-9,5(-10,3) \times 2,0-2,5(-3,5) \mathrm{cm}$, alterno, elíptico, base obtusa a atenuada, ápice acuminado, concolor, face adaxial glabra, face abaxial esparsamente ferrugíneovilosa a glabrescente; venação broquidódroma. Racemo simples, 4-8cm; bráctea caduca; bractéola linear, persistente. Flor 1,3-1,5cm; pedicelo ca. $1 \mathrm{~mm}$; cálice campanulado, tomentoso externamente, tubo calicino 8-10mm, lacínios superiores, laterais e mediano semelhantes no tamanho, ca. $1 \mathrm{~mm}$; corola branca; vexilo $8-10 \mathrm{~mm}$, orbicular, ungüiculado; alas ca. $8-9 \mathrm{~mm}$; pétalas da carena levemente menores que às alas; estames diadelfos 9+1, filetes glabros; ovário estipitado, estípite ca. $2 \mathrm{~mm}$, esparsamente ferrugíneo-viloso; estilete levemente curvado, glabro. Sâmara $6-8 \mathrm{~cm}$, estípite $7-15 \mathrm{~mm}$, falciforme, glabra, base e ápice obtusos; região do núcleo seminífero ca. $1 \mathrm{~cm}$ larg., castanho-escura; asa 1,0-1,5cm larg., oblonga, reticulada, castanha quando madura.

Material examinado: BRASIL. Minas Gerais: Marliéria, PERD, margem da Lagoa do Aníbal, XII/1998 (fr.), Bortoluzzi 408 et al. (VIC, PERD); Viçosa, E.S.A.U., X/1935 (fl.), Kuhlmann s.n. (VIC 2221).

M. triste e $M$. oblongifolium mostraram ser espécies muito polimorfas quanto à forma e tamanho dos folíolos; ambas apresentam em comum os folíolos glabros na face adaxial e velutino-ferrugíneo na abaxial. Os caracteres que auxiliaram na separação dessas espécies foram o tipo de ápice dos folíolos e a forma da sâmara. M. triste apresenta o ápice dos folíolos acuminado e sâmara falciforme, enquanto $M$. oblongifolium exibe o ápice dos folíolos obtuso a agudo e sâmara cultriforme, não incurvada na região do núcleo seminífero (Fig. 37). Mendonça Filho (1996) sinonimizou $M$. triste em $M$. brasiliense Vog., no entanto, no presente estudo $M$. triste foi tratada como espécie distinta, corroborando com as observações de Sartori \& Tozzi (1998). É citada para o Espírito Santo e Rio de Janeiro (Lima et al. 1994), Minas Gerais (Mendonça Filho 1996) e São Paulo (Sartori \& Tozzi 1998).

5. Platycyamus Benth, Fl. Bras. 15(1): 323. 1862.

Árvore, inerme. Folha trifoliolada; estípula e estipela persistentes. Panícula terminal; bráctea e bractéola caducas. Cálice campanulado, 5-laciniado, lacínios superiores 2 , unidos até quase ao ápice, lacínios inferiores 3 , desiguais, sendo o mediano maior que os laterais; corola violácea, esbranquiçada após a antese; vexilo obovadoorbicular, reflexo, ápice emarginado, curto-ungüiculado, glabro; alas oblongas, ungüiculadas; pétalas da carena curvadas, ungüiculadas, completamente fundidas dorsalmente com tamanhos semelhantes ao vexilo e às alas; estames diadelfos, filetes glabros, anteras oblongas, deiscência longitudinal; ovário séssil; estilete reto, glabro; estigma terminal. Legume oblongo, plano, reticulado, deiscente em ambas as margens; polispérmico.

5.1. Platycyamus regnellii Benth., Fl. Bras. 15(1): 323. 1862.

Fig. 42.

Árvore ca. 15-20m alt. Tronco com exsudato vermelho quando injuriado, ramo pubérulo ou glabro, lenticelado. Folha caduca no período reprodutivo; estípula e estipelas lineares; pecíolo 5,0-10,5cm; raque 2,5-6,0cm; folíolos laterais assimétricos; folíolo terminal $12-25 \times 8,8-14 \mathrm{~cm}$, ovado ou romboidal, base cuneada, ápice agudo, concolor, face adaxial pubérula a glabra, face abaxial pubescente, venação broquidódroma. Panícula 20-40cm terminal, castanho-escura; bráctea triangular; bractéola lanceolada. Flor 2,0-2,5cm; pedicelo 5-9mm; cálice velutino externamente, hialino-seríceo 
internamente, persistente no fruto, tubo calicino $5-7 \mathrm{~mm}$, lacínios superiores e laterais semelhantes no tamanho, 5,0-6,5mm, lacínio mediano 7-8mm; pétalas de tamanhos semelhantes 20-25cm; estames diadelfos 9+1; ovário viloso. Legume 15,5-21,5cm, séssil, oblongo, plano, achatado, ferrugíneo-tomentoso, base cuneada, ápice agudo, reticulado, alado e estriado dorsalmente.

Material examinado: BRASIL. Minas Gerais: Marliéria, PERD, estrada do restaurante, IV/1997 (fl.) Lopes 116 (VIC); Ponte Queimada, IV/1998 (fl.), Bortoluzzi et al. 108 (VIC); trilha da Lagoa do Meio IV/1998 (fl.), Bortoluzzi et al. 118 (VIC); VI/1998 (fr.), Bortoluzzi et al. 177 (VIC, PERD); Ponte Queimada IV/1999 (fl.), Bortoluzzi et al. 599 (VIC, PERD); V/1999 (fl.), Bortoluzzi et al. 652 (VIC).

As folhas trifolioladas; inflorescências em panículas terminais; corola violácea no botão, esbranquiçada após a antese e frutos planos, achatados, alados e com estrias longitudinais na margem superior foram os caracteres utilizados na identificação de $P$. regnellii. Ocorre às margens de trilhas e interior de mata. Distribui-se nos Estados de Goiás, sul da Bahia, Espírito Santo, Minas Gerais e São Paulo, principalmente na floresta semidecídua de altitude (Lorenzi 1992).

\section{Platypodium Vog., Linnaea, 11. 420. 1837.}

Árvore, inerme. Folha pinada, imparipinada; estípula caduca; estipela nula. Racemo axilar ou terminal, bráctea caduca; bractéola tardiamente caduca. Cálice campanulado, 5-laciniado, lacínios superiores 2, semi-soldados; lacínios inferiores 3, todos semelhantes no tamanho; corola amarela; vexilo obovado a orbicular, ápice emarginado, curto-ungüiculado, glabro; alas oblongas, ungüiculadas, maiores que a carena; pétalas da carena oblongas, ungüiculadas, fundidas no dorso; estames poliadelfos, filetes glabros, anteras oblongas, deiscência longitudinal; ovário estipitado; estilete curvo, glabro; estigma terminal. Sâmara oblonga, região do núcleo seminífero distal; monospérmica, raramente dispérmica.

6.1. Platypodium elegans Vog., Linnaea 11: 422.1837. Fig. 43-44.

Nomes populares no PERD: jacarandá-branco, uruvalheiro.

Árvore ca. 7-15m alt. Ramo pubérulo a glabro, lenticelado. Folha 12-21-foliolada; pecíolo 1,5-2,0cm; raque $9-14 \mathrm{~cm}$; folíolo $2-4 \times 1,0-1,5 \mathrm{~cm}$, alterno, oblongo, base obtusa, ápice obtuso, emarginado, face adaxial glabra ou pubérula na nervura mediana, face abaxial castanho-pubérula; venação camptódroma. Racemo 7-14cm; bráctea deltóide; bractéola elíptica. Flor 1,7-2,0cm; pedicelo 7-9mm; cálice glabro externamente, hialino-seríceo internamente, persistente no fruto, tubo calicino ca. $8 \mathrm{~mm}$, lacínios superiores, laterais e mediano $3-4 \mathrm{~mm}$; corola amarela; vexilo $16-18 \times 15 \mathrm{~mm}$; alas 12-15×6-7mm; pétalas da carena 10-12×3-4mm; ovário glabro, estípite do ovário 2-3mm. Sâmara 7,5-9,0×3,5cm, estípite 3,5-7,0mm, cartácea, base cuneada, ápice obtuso; região do núcleo seminífero 1,2-2,5cm larg.; asa 2,0-2,8cm larg., estriada, venação oblíqua.

Material examinado: BRASIL. Minas Gerais: Marliéria, PERD, região do vinhático, XI/1997 (fl.), Lopes 480 (VIC); XII/1997 (fr.), Lopes 516 (VIC); trilha da Mombaça, VI/1998 (fr.), Bortoluzzi et al. 81 (VIC); trilha do Aníbal, VIII/1998 (fr.), Bortoluzzi et al. 210 (VIC); Ponte Queimada, IV/1998 (fr.), Bortoluzzi et al. 111 (VIC); estrada que corta o Parque, X/1998 (fl.), Bortoluzzi 298 et al. (VIC).

Platypodium elegans difere das demais espécies arbóreas ocorrentes no PERD por apresentar os folíolos oblongos, discolores, ápice emarginado, venação proeminente em ambas as faces dos folíolos e as sâmaras com a região do núcleo seminífero distal (Fig. 44), além da venação oblíqua nas asas das sâmaras, características que a diferencia das espécies de Machaerium. Ocorre às margens de trilhas, estrada e interior de mata. É citada nos Estados de São Paulo, Rio de Janeiro, Minas Gerais e Espírito Santo por Lorenzi (1992) e Mendonça Filho (1996).

\section{Pterocarpus L., Fl. Zeyl.: 196. 1747.}

Árvore. Folha pinada, imparipinada; folíolo alterno; estípula caduca; estipela nula. Racemo ou panícula, axilar; bráctea e bractéola caducas ou persistentes. Cálice turbinado-campanulado, 5 laciniado; lacínios superiores 2, soldados até quase ao ápice, lacínios inferiores 3, semelhantes no tamanho; corola amarela; vexilo orbicular, ungüiculado, emarginado, glabro; alas oblongas, ungüiculadas, maiores que a carena; pétalas da carena falcadas, ungüiculadas, fundidas dorsalmente; estames monadelfos ou diadelfos, filetes glabros, anteras oblongas, deiscência longitudinal; ovário séssil ou estipitado; estilete reto, glabro; estigma terminal. Sâmara orbicular, suborbicular a obovada, alada, asa circular; região do núcleo seminífero central; monospérmica.

7.1. Pterocarpus rohrii Vahl, Symb. Bot. 2: 79. 1791. Fig. 45-46.

Árvore ca. $15-20 \mathrm{~m}$ alt. Tronco com exsudato vermelho quando injuriado, ramo glabro, lenticelado. 

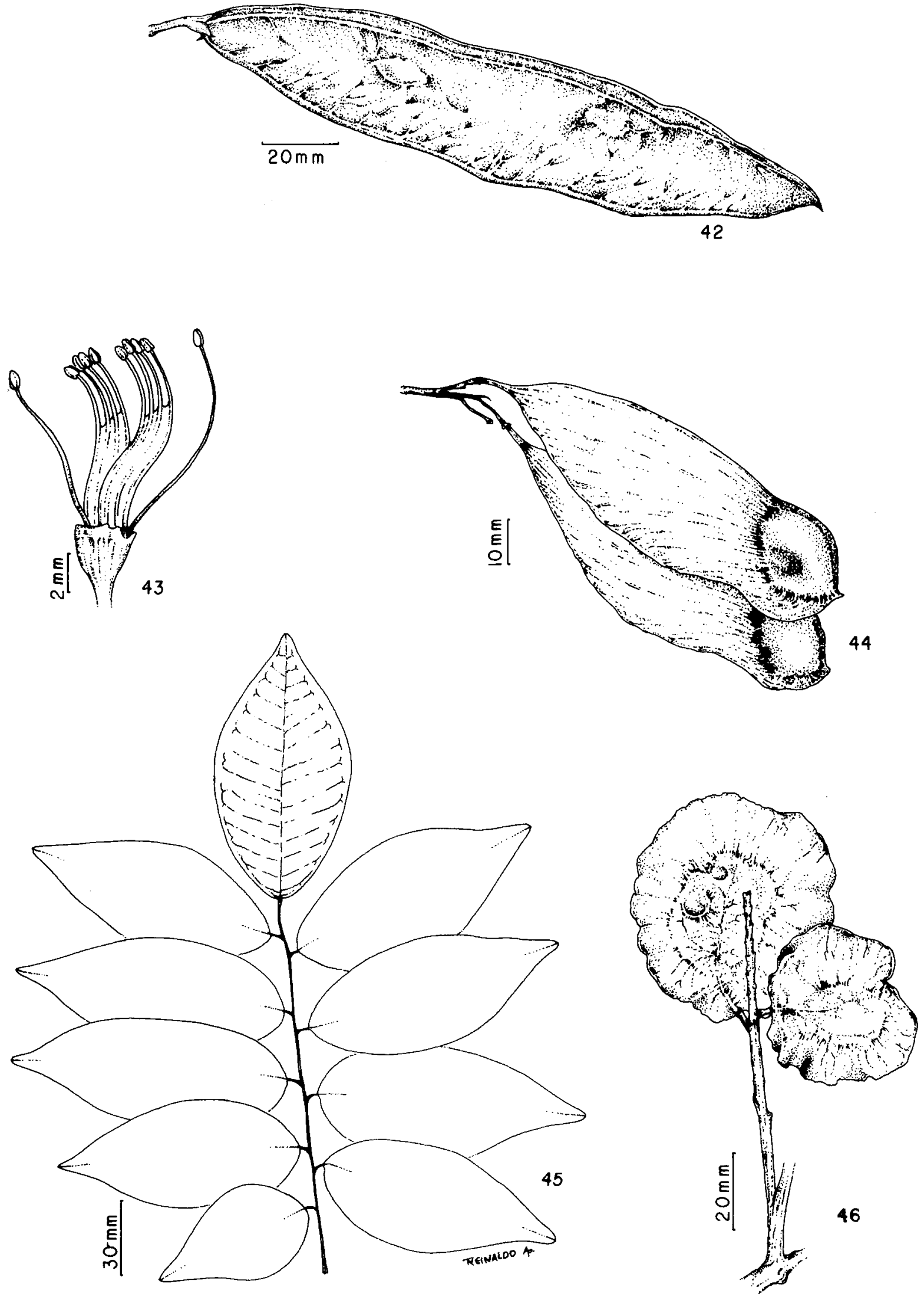

Figura 42. Platycyamus regnellii. 42. Fruto (Bortoluzzi et al. 177). Figuras 43-44. Platypodium elegans. 43. Androceu. 44. Frutos (Lopes 480 e Bortoluzzi et al. 210). Figuras 45-46. Pterocarpus rohrii. 45. Folha. 46. Fruto (Bortoluzzi et al. 262). 
Folha 5-10-foliolada; pecíolo 6-10cm; raque 4,5-7,0cm; folíolo $10-12 \times 3,6-4,5 \mathrm{~cm}$, alterno, raramente oposto ou suboposto, elíptico a obovado, base obtusa a atenuada, ápice obtuso a acuminado, coriáceo, concolor, face adaxial glabrescente e abaxial esparsamente ferrrugíneo-pubescente, principalmente na nervura mediana; venação broquidódroma, proeminente na face abaxial. Racemo ou panícula 9-13cm; bráctea e bractéola ovado-lanceoladas, persistentes. Flor 1,0-1,5cm; pedicelo $5-10 \mathrm{~mm}$; cálice tomentoso externamente, glabro internamente, tubo calicino 4-5mm, lacínios superiores, levemente subtruncados, lacínios laterais e mediano ca. $2 \mathrm{~mm}$, corola amarela; vexilo $11-13 \times 10-12 \mathrm{~mm}$, com mácula vinácea no centro; alas $13-14 \times 3-4 \mathrm{~mm}$; carena 9-10×3-4mm; estames monadelfos 10; ovário séssil, viloso. Sâmara 4,0-5,5cm, suborbicular a obovada; asa circular, membranácea, castanho-escura quando madura.

Material examinado: BRASIL. Minas Gerais: Marliéria, PERD, região do Vinhático, XI/1997 (fl.), Lopes 488 (VIC); trilha da Lagoa do Meio, IX/1998 (fr.), Bortoluzzi et al. 262 (VIC, PERD).

Pterocarpus rohrii pode ser reconhecida pelas folhas com 5-10 folíolos (Fig. 45) esparsamente ferrugíneo-pubescentes na face abaxial; corola amarela com mácula vinácea no vexilo e pelas sâmaras suborbiculares a obovadas com a região do núcleo seminífero central (Fig. 46). Ocorre no interior de mata, em local seco. É largamente distribuída pela América tropical, desde o México até Santa Catarina no Sul do Brasil (Rojo 1972).

\section{Swartzia Schreb., Gen. Pl. 2: 518. 1791.}

Árvore ou arbusto. Folha 1-plurifoliolada, imparipinada; estípula persistente ou caduca; estipela geralmente persistente; pecíolo e raque alados ou canaliculados. Racemo, panícula ou fascículo de racemos, axilar, extra-axilar ou caulifloro, em ramos áfilos; bráctea persistente; bractéola geralmente persistente, raramente nula. Cálice inteiro no botão, rompendo-se em segmentos irregulares na antese; corola 0-1 pétala, geralmente branca ou amarela, suborbicular, ovada, elíptica ou oblada, geralmente ungüiculada, glabra; estames dimorfos, 2-11 maiores, ca. 100 menores, antera oblonga, ovada ou oblada, deiscência longitudinal; ovário estipitado; estilete terminal ou lateral, reto ou curvado; estigma terminal. Legume ou legume nucóide, oblongo, ovóide a globoso, moniliforme a achatado; mono ou polispérmico; sementes 1-15, ariladas, arilo branco ou laranja.
8.1. Swartzia apetala Raddi var. apetala, Mem. Mat. Fis. Soc. Ital. Sci. Modena 18(2): 398. 1820.

Fig. 47-48.

Árvore 4-8,5m alt. Ramo estrigoso a glabrescente. Folha 5-9-foliolada; pecíolo 2,5-4,5cm, estreitamente alado, raque $8,0-13,5 \mathrm{~cm}$, levemente alada a canaliculada, ala ca. $2 \mathrm{~mm}$; estipela persistente; folíolo 7,0-9,7× 2,4-4,4cm, oposto, elíptico, base cuneada, ápice acuminado a obtuso, às vezes retuso, pubérulo a glabro na face adaxial, pubérulo na face abaxial; venação broquidódroma, proeminente na face abaxial e sulcada na adaxial. Panícula ou fascículo de racemos axilar ou caulifloro, $6,5-17 \mathrm{~cm}$; bráctea triangular, persistente; bractéola nula. Botão floral 2,5-4,0mm diâm., ovado a globoso, glabro. Flor $0,5-1,2 \mathrm{~cm}$; pedicelo $5-9 \mathrm{~mm}$; cálice 3-4-segmentado, tomentoso externamente, glabro internamente, pétala ausente; estames 2-3 maiores, filetes glabros, anteras oblongas; ovário estipitado, estípite 2,3-3,0mm, glabro, estilete lateral. Legume 1,7-3,5×0,8-2,4cm, ovóide a globoso, glabro, às vezes áspero externamente, alaranjado; monospérmico; semente preta com arilo branco.

Material examinado: BRASIL. Minas Gerais: Marliéria, PERD, Portaria, X/1993 (fl.), Drumond s.n. (PERD 33); Mombaça, X/1993 (fl.), Costa et al. s.n. (PERD 93); atrás do laboratório do parque, III/1995 (fl.), Costa et al. s.n. (PERD 72); região do Vinhático, II/1997 (fr.), Lopes 341 (VIC); atrás do mirante, IV/1997 (fr.), Lopes 357 (VIC); próximo à casa de tábua, IX/1997 (fl.), Lopes 379 (VIC); à beira da Lagoa D. Helvécio, X/1997 (fl.), Lopes 423 (VIC); região do vinhático, X/1997 (fl.), Lopes 438 (VIC); trilha de Porto Capim, X/1997 (fr.), Bovini 1229 (VIC); trilha da Garapa Torta, IV/1998 (fr.), Bortoluzzi et al. 114 (VIC); trilha do Aníbal, IV/1998 (fr.) Bovini \& Marquinhos 1361 (VIC); trilha da Lagoa do Meio, V/1998 (fr.), Bortoluzzi et al. 135 (VIC); trilha do Aníbal, VI/1998 (fr.), Bortoluzzi et al. 162 (VIC), trilha do Aníbal, VIII/1999 (fr.), Bortoluzzi et al. 234 (VIC).

Swartzia apetala var. apetala caracteriza-se pelas flores apétalas, legumes ovóides a globosos, alaranjados, monospérmicos e sementes pretas com arilo branco. No PERD, além da variedade típica, ocorre também $S$. apetala var. glabra (Vog.) R.S. Cowan, coletada na região sul do parque, fora da área de estudo. Ambas distinguem-se pelo tamanho do pedicelo e pela coloração do gineceu concordando com as observações de Mansano \& Tozzi (1999) onde, na variedade típica, o pedicelo mede 5-9mm compr. e o gineceu apresenta-se preto no material herborizado, enquanto em $S$. apetala 
var. glabra o pedicelo mede $9-20 \mathrm{~mm}$ compr. e o gineceu apresenta-se verde no material herborizado. No PERD, $S$. apetala var. apetala ocorre nas margens de lagoas, estrada e interior de mata. É amplamente distribuída no leste de Minas Gerais, Rio de Janeiro e Espírito Santo, principalmente na região litorânea, além dos Estados de Alagoas e da Bahia (Mansano \& Tozzi 1999).

8.2. Swartzia flaemingii var. psilonema (Harms) R. S. Cowan, Fl. Neotropica 1: 105. 1967.

Swartzia psilonema Harms, Bot. Jahrb. 42: 211. 1908.

Fig. 49-50.

Nome popular no PERD: banha-de-galinha.

Árvore ca. 30-35m alt. Tronco com exsudato vermelho, quando injuriado, ramo pubérulo a glabrescente. Folha 27-35-foliolada; estípula caduca; estipela persistente; pecíolo sulcado ventralmente $0,6-1,8 \mathrm{~cm}$; raque alada, ala menor que $1 \mathrm{~mm}$; folíolo 1,8-2,6×0,3-0,7cm, oposto, oblongo, base obtusa, ápice obtuso a levemente retuso, face adaxial glabra, face abaxial ferrugíneo-tomentosa; venação broquidódroma. Racemo ou panícula $5-55 \mathrm{~cm}$, cauliflora; bractéola persistente, inserida na metade do pedicelo. Botão floral 7-10mm diâm., globoso, estrigoso. Cálice 4-segmentado, pubescente externamente, glabro internamente; pétala 5-13 $\times 10-18 \mathrm{~mm}$, oblada, vilosa no dorso; estames maiores 2-4, filetes glabros, anteras oval-oblongas; ovário piloso; estilete termnal. Legume 4,8-10×4,5-6,5cm, longopedunculado; pedúnculo $2,5-7,5 \mathrm{~cm}$, elíptico a globoso, verruculoso, tomentoso a glabrescente, ferrugíneo quando maduro; polispérmico; sementes 3-7, cremes com arilo laranja.

Material examinado: BRASIL. Minas Gerais: Marliéria, PERD: trilha da Garapa Torta, VII/1998 (fr.), Bortoluzzi et al. 197 (VIC, PERD).

Swartzia flaemingii var. psilonema caracteriza-se pelas folhas com 27-35 folíolos, oblongos, pequenos, $1,8-2,6 \mathrm{~cm}$ compr. e frutos globosos, tomentosos a glabrescentes (Fig. 50) com sementes creme e arilo laranja cobrindo quase toda a sua superfície. Dos representantes de Swartzia coletados no PERD, este foi o táxon que apresentou os folíolos menores e em maior número. S. flaemingii var. psilonema difere da variedade típica que apresenta os estames maiores com os filetes densamente vilosos (Cowan 1967). A presença deste táxon no Estado de Minas Gerais está sendo confirmada, corroborando com as citações de Cowan (1967) e Mendonça Filho (1996). Este é o primeiro registro de material com folhas e frutos deste táxon para o sudeste brasileiro. Cowan (1967) mencionou 15-20m de altura para $S$. flaemingii var. psilonema e frutos com 1-3 sementes. Entretanto, no PERD foi observado indivíduo atingindo cerca de $30-35 \mathrm{~m}$ alt. e frutos com 3-7 sementes. O arilo das sementes é usado para o preparo de sucos, na região do PERD (Waldemar Queiroga 1999, com. pess.). No PERD, este táxon foi coletado no interior de mata, na trilha da Garapa Torta. Sua ocorrência abrange o nordeste do Pará, norte de Goiás e regiões costeiras até o interior do Maranhão, Piauí, Ceará, Bahia e região sul de Minas Gerais (Cowan 1967).

\subsection{Swartzia multijuga Vogel, Linnaea 11: 175. 1837.}

Árvore ca. 5m alt. Ramo tomentoso a glabrescente. Folha 27-29-foliolada; estípula caduca; estipela persistente; pecíolo 1,2-2,6cm, estreitamente alado; ala 1,5-2,0mm; raque foliar $10,5-16,5 \mathrm{~cm}$, glabrescente, alada; ala semelhante à do pecíolo; folíolo 2,7-6,7×0,7-1,2cm, oposto, oblongo, base assimétrica a obtusa, ápice obtuso a agudo, face adaxial esparsamente pubescente, face abaxial denso pubescente a tomentosa; venação broquidódroma, proeminente na face abaxial; folíolos basais geralmente menores. Panícula 22-38cm, cauliflora, inserida em ramos áfilos, pêndula; bráctea triangular, persistente; bractéola inserida acima da metade do pedicelo. Botão floral 0,5-0,6mm diâm., oval, tomentoso. Flor 1,5-2,5cm; pedicelo 1,5-2cm; cálice 4-5 segmentado, tomentoso externamente, glabro internamente; pétala 1,3-1,5×1,3-1,6mm, branca, oblada; estames maiores 4-5, filetes pilosos, anteras oblongas; ovário glabro, estipitado, estípite 4,5-6mm, oblongo, curvado, glabro; estilete lateral. Legume nucóide ca. $11,6 \times 5,4 \mathrm{~cm}$, oblongo, glabro, amarelo; polispérmico; sementes 8-14, cremes com arilo laranja.

Material examinado: BRASIL. Minas Gerais: Marliéria, PERD, local não-determinado, XI/1999 (fl.), Silva 1605 (VIC); estrada que corta o parque, próximo à Ponte Queimada, VIII/1999 (fl.), Bortoluzzi et al. 686 (VIC).

Swartzia multijuga apresenta folhas com 27-29 folíolos, esparsamente pubescentes na face adaxial e densamente pubescentes a tomentosos na face abaxial; inflorescências paniculadas pêndulas e ovário glabro. No PERD, S. multijuga assemelha-se a S. flaemingii var. psilonema, mas esta última possui folhas com folíolos de menor tamanho (1,8-2,6cm compr.), além de apresentar ovário piloso e frutos globosos, tomentosos a glabrescentes. S. multijuga ocorre no litoral do Espírito Santo e em Minas Gerais, principalmente na cadeia do Espinhaço e no vale do Rio Doce (Mansano \& Tozzi 1999). 
8.4. Swartzia myrtifolia var. elegans (Schott) R. S. Cowan, Fl. Neotropica 1: 168. 1968.

Swartzia elegans Schott, Syst. Veg. 4(2): 407. 1827. Fig. 51-52.

Nome Popular no PERD: laranjinha.

Árvore ca. 6-8m alt. Ramo pubérulo a glabrescente. Folha 3-5-foliolada; pecíolo 0,3-1,0cm, alado; ala 1-2mm larg.; raque $1-3 \mathrm{~cm}$, alada; ala $2-3 \mathrm{~mm}$; folíolo $5-7,8 \times$ 2,3-3,7cm, oposto, forma variável, ovado a obovado (o terminal amplo-elíptico), base cuneada a aguda, ápice agudo a acuminado, retuso, face adaxial glabra, face abaxial glabra a pubérula; venação broquidódroma; os folíolos basais geralmente menores. Racemo, axilar ou terminal com ca. 3 flores, $2,5-5,0 \mathrm{~cm}$; bráctea persistente; bractéola linear, persistente. Botão floral 5-8×4-7mm diâm., oval a globoso, pubérulo. Flor 2,5-3,0cm; pedicelo 11-17mm; cálice 4-segmentado, glabro; pétala 20-24× 23-30mm, oblada a cordada, amarela; estames maiores 4-8, filetes glabros, anteras oblongas; ovário estipitado, estípite $10-13 \mathrm{~mm}$, glabro; estilete reto, terminal. Legume 3,3-4,0×1,0-1,4cm, elíptico ou moniliforme, glabro, alaranjado; mono ou dispérmico; semente preta com arilo branco.

Material examinado: BRASIL. Minas Gerais: Marliéria, PERD, região do Vinhático, II/1995 (st.) Costa s.n. (PERD 68); XI/1996 (fl.), Lopes 196 (VIC); estrada do Restaurante, III/1998 (fr.), Lopes 113 (VIC); trilha da Lagoa do Meio, V/1998 (fr.), Bortoluzzi et al. 141 (VIC, PERD).

Dos representantes de Swartzia coletados no PERD, S. myrtifolia var. elegans é o único que apresenta folhas com três ou cinco folíolos no mesmo indivíduo (Fig. 51) e corola amarela. Os frutos de S. myrtifolia var. elegans e S. apetala var. apetala são muito semelhantes quanto a coloração da semente e do arilo. No entanto, estes táxons podem ser diferenciados pelo número de folíolos e forma dos frutos; no primeiro com 3-5 folíolos e frutos elípticos ou moniliformes e no último com 5-7 folíolos e frutos ovóides ou globosos. No PERD, S. myrtifolia var. elegans ocorre no interior de mata e margens de trilhas. Ocorre nos Estados de Minas Gerais, Espírito Santo e Rio de Janeiro (Mansano \& Tozzi 1999).

8.5. Swartzia oblata R.S. Cowan, Brittonia 33(1): 11. 1981.

Fig. 53-54.

Árvore 5-20m alt. Ramo glabrescente. Folha 9-19-foliolada; estípula e estipela persistentes; pecíolo $2,0-3,5 \mathrm{~cm}$, marginado; raque $11,5-22,5 \mathrm{~cm}$, sulcada ventralmente; folíolo $7-11 \times 2,5-5 \mathrm{~cm}$, oposto, elíptico, base cuneada, ápice agudo a acuminado, face adaxial e abaxial glabrescentes; venação broquidódroma proeminente principalmente na face abaxial; bráctea triangular, caduca; bractéola inserida acima da metade ou no ápice do pedicelo, persistente. Racemo ou panícula, axilar ou caulifloro, em ramo áfilo. Botão floral globoso 4,5-7,0mm diâm. Flor 1,5-1,8cm; pedicelo 8-10mm; cálice com quatro segmentos, tomentoso externamente, glabro internamente; pétala $15-19 \times 20-23 \mathrm{~mm}$, oblada, branca; estames maiores 2-3, filetes pilosos, anteras oblongas; ovário 5,8-7,0×2-3mm, estipitado, estípite 3,5-4mm, seríceo; estilete lateral, curvado. Legume nucóide $6,0-12,5 \times 2,8-4,0 \mathrm{~cm}$, elíptico ou oblongo, estriado transversalmente, glabrescente; polispérmico; sementes 1-7, cremes com arilo laranja.

Material examinado: BRASIL. Minas Gerais: Marliéria, PERD, trilha da Mombaça, VIII/1998 (fr.), Bortoluzzi et al. 247 (VIC); estrada que corta o parque, II/1999 (fl.), Bortoluzzi et al. 510 (VIC); trilha do Aníbal, III/1999 (fl.), Bortoluzzi et al. 566 (fl.), (VIC); trilha de Porto Capim, V/1999 (fr.), Bovini 1.409 \& Moraes (VIC).

As folhas com 9-19 folíolos, bractéolas persistentes no pedicelo, flores com uma pétala branca e frutos elípticos mais longos do que largos (Fig. 54), glabros e estriados transversalmente caracterizam $S$. oblata. As flores e, principalmente, as folhas de $S$. oblata assemelham-se às de S. acutifolia Vogel var. acutifolia, sendo facilmente confundidas; essas espécies podem ser diferenciadas pela ausência de bractéolas, gineceu tomentoso e fruto mais largo do que longo em S. acutifolia var. acutifolia, o que corrobora as observações de Mansano \& Tozzi (2001). Em muitos herbários esta espécie aparece identificada como S. acutifolia var. ynesiana. No entanto, Mansano \& Tozzi (2001) sinonimizaram esta variedade com S. oblata. No PERD, ocorre às margens de trilhas, da estrada principal e do Ribeirão do Turvo. É encontrada nos Estados de São Paulo, Rio de Janeiro, Minas Gerais e Espírito Santo (Mansano \& Tozzi 1999).

O levantamento das Papilionoideae no PERD resultou em 22 táxons arbóreos e arbustivo-escandentes, pertencentes a oito gêneros. Machaerium e Swartzia foram os gêneros com o maior número de espécies, oito e cinco, respectivamente. Dalbergia com três, Erythrina com duas e os demais gêneros, Lonchocarpus, Platycyamus, Platypodium e Pterocarpus com uma espécie cada.

Dalbergia nigra, Platycyamus regnellii, Swartzia apetala var. apetala e S. myrtifolia var. elegans 


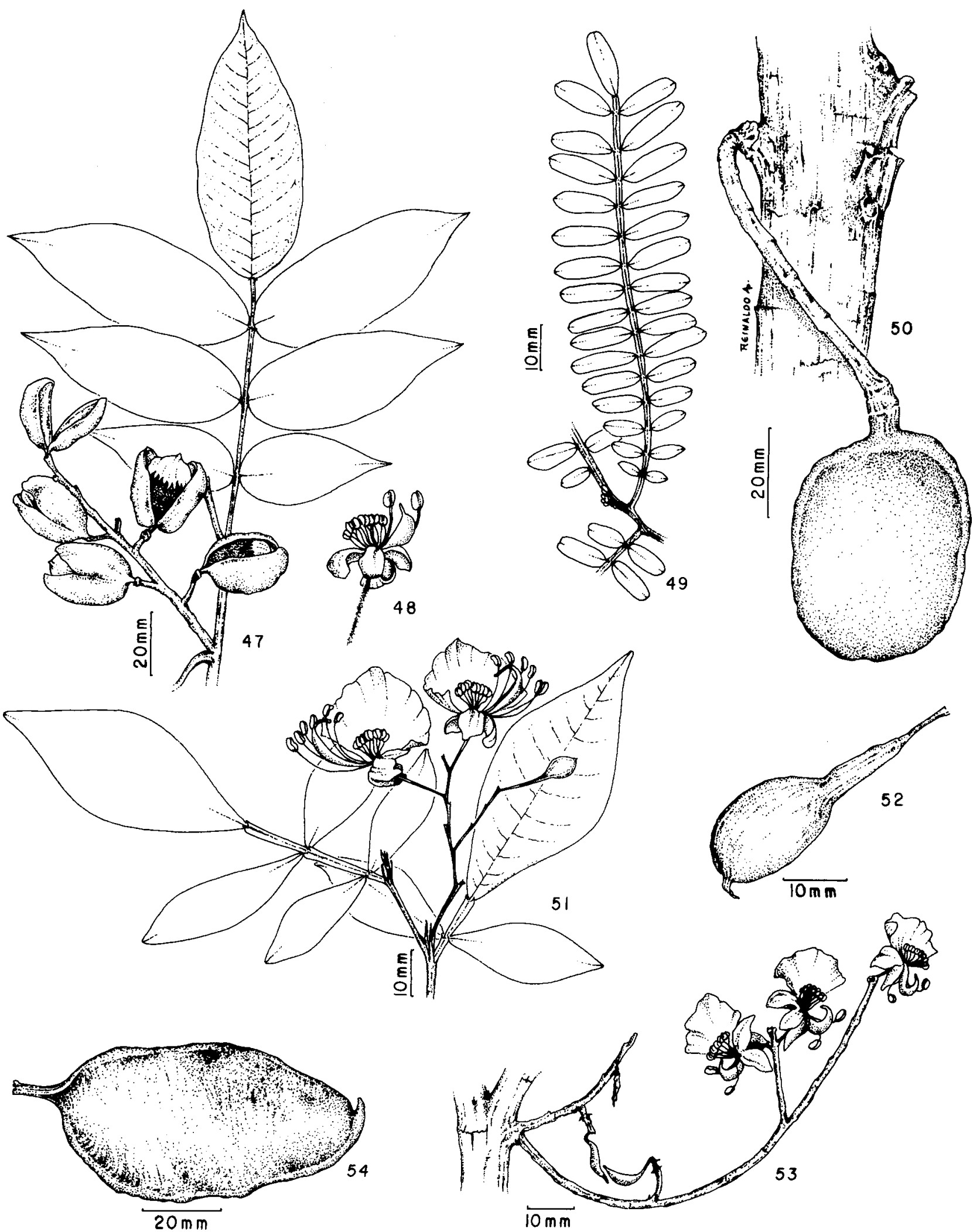

Figuras 47-48. Swartzia apetala var. apetala. 47. Ramo com frutos (Bortoluzzi et al. 135). 48. Flor (Lopes 379). Figuras 49-50. Swartzia flaemingii var. psilonema. 49. Folha. 50. Fruto (Bortoluzzi et al. 197). Figuras 51-52. Swartzia myrtifolia var. elegans. 51. Ramo com flores (Lopes 196). 52. Fruto (Bortoluzzi et al. 141). Figuras 53-54. Swartzia oblata. 53. Inflorescência (Bortoluzzi et al. 566). 54. Fruto (Bortoluzzi et al. 247). 
ocorreram na maioria das trilhas; os demais táxons restringiram-se a uma ou poucas trilhas.

Das trilhas estudadas, a estrada que corta o parque e a trilha do Aníbal, que ocorrem próximas ao Rio Doce, apresentaram o maior número de táxons, 15 e 12, respectivamente, em sua grande parte com áreas abertas e vegetação alterada. O menor número de táxons, cinco, foi observado na trilha da Garapa Torta, sendo esta a mais afastada do Rio Doce, além de estar sob constante influência de inundações periódicas.

De forma geral, a similaridade entre as trilhas foi baixa, inferior a $20 \%$, evidenciando a grande heterogeneidade florística encontrada nas trilhas estudadas, indicando a importância da preservação de toda a área, para que seja garantida a diversidade de espécies.

\section{Agradecimentos}

Os Autores agradecem à Coordenação de Aperfeiçoamento de Pessoal de Nível Superior (CAPES) e à Fundação de Amparo à Pesquisa do Estado de Minas Gerais (FAPEMIG), pela bolsa concedida à primeira Autora; ao Instituto Estadual de Florestas (IEF), pela estrutura física concedida; aos funcionários do PERD pelo auxílio e presteza; aos curadores dos herbários visitados; aos amigos Waldemar Queiroga, Rogério M. Pereira e G. S. Adriano (Canela) e Marquinhos, pelo auxílio nos trabalhos de campo; ao Guilherme A. P. Moraes, pelo auxílio no laboratório; ao Reinaldo A. Pinto, pelas ilustrações; aos assessores da Revista Acta Botanica Brasilica, pelas valiosas sugestões.

\section{Referências bibliográficas}

Almeida, D. G. 1953. Dalbergia frutescens (Vell.) Britton. Arquivos do Jardim Botânico do Rio de Janeiro 5: 15-34.

Barroso, G. M. 1964. Leguminosas da Guanabara. Arquivos do Jardim Botânico do Rio de Janeiro 18: 109-177.

Bortoluzzi, R. L. C.; Garcia, F. C. P.; Carvalho-Okano, R. M. \& Tozzi, A. M. G. A. 2003. Leguminosae-Papilionoideae no Parque Estadual do Rio Doce, Minas Gerais, Brasil. I: trepadeiras e subarbustos. Iheringia série Botânica 58(1): 25-60.

Bovini, M. G.; Carvalho-Okano, R. M. \& Vieira, M. F. 2001. Malvaceae A. Juss. no Parque Estadual do Rio Doce, Minas Gerais, Brasil. Rodriguésia 52(81): 17-47.

Brummitt, R. K. \& Powell, C. E. 1992. Authors of plant names. Royal Botanic Gardens, Kew.

Carvalho, A. M. 1997. A synopsis of the genus Dalbergia (Fabaceae: Dalbergieae) in Brazil. Brittonia 49(1): 87-109.
Carvalho, I. R.; Gentilini, E. \& Teixeira, M. C. B. 1983. Levantamento da vegetação do Parque Estadual do Rio Doce. Revista Som 27: 3-25,

Cowan, R. S. 1967. Swartzia (Leguminosae, Caesalpinioideae, Swartzieae). Flora Neotropica 1: 1-228.

Gilhuis, J. P. 1986. Vegetation survey of the Parque Florestal Estadual do Rio Doce, MG, Brasil. Dissertação de Mestrado. Universidade Federal de Viçosa, Viçosa.

Giulietti, A. M. \& Foreiro, E. 1990. "Workshop" diversidade taxonômica e padrões de distribuição das angiospermas brasileiras. Acta Botanica Brasilica 4(1): 3-10.

Graçano, D.; Prado, J. \& Azevedo, A. A. 1998. Levantamento preliminar de Pteridophyta do Parque Estadual do Rio Doce (MG). Acta Botanica Brasilica 12(2): 165-181.

Gonçalves, A. P. S. 2000. Bambus (Bambusoideae s.l.: Poaceae) no Parque Estadual do Rio Doce, MG, Brasil. Dissertação de Mestrado. Universidade Federal de Viçosa, Viçosa.

Gunn, C. R. 1981. Seeds of Leguminosae. Pp. 913-25. In: Polhill, R. M. \& Raven, P. H. (eds.). Advances in legume systematics, Crown, Kew.

Hoehne, F. C. 1941. Leguminosas-Papilionadas: gêneros Machaerium e Paramachaerium. Pp. 1-99. In: Hoehne, F. C. Flora Brasilica. Secretaria da Agricultura do Estado de São Paulo, São Paulo.

Hickey, L. J. 1973. Classification of the architecture of dicotyledonous leaves. American Journal of Botany 60(1): 17-33.

Krukoff, B. A. \& Barneby, R. C. 1974. Conspectus of species of the genus Erythrina. Lloydia 37(3): 332-459.

Lackey, J. A. 1981. Phaseoleae. Pp. 301-327. In: Polhill, R. M., Raven, P. H. (eds.). Advances in legume systematics. Royal Botanic Gardens, Kew.

Lewis, G. P. 1987. Legumes of Bahia. Royal Botanic Gardens, Kew.

Lima, H. C. 1983. Novos taxa de Leguminosae-Papilionoideae (tribo Dalbergieae) do Brasil. Bradea 3(45): 399-405.

Lima, H. C.; Correia, C. M. B. \& Farias, D. S. 1994. Leguminosae. Pp. 167-228. In: Lima, M. P. M. \& R. R. Guedes-Bruni (orgs.). Reserva Ecológica de Macaé de Cima: Nova Friburgo - RJ: aspectos florísticos das espécies vasculares. Jardim Botânico do Rio de Janeiro, Rio de Janeiro.

Lima, H. C. 1995. Leguminosas da Flora fluminensis - J. M. da C. Vellozo - lista atualizada das espécies arbóreas. Acta Botanica Brasilica 9(1): 123-146.

Lima, H. C. \& Fortunato, R. H. 1998. Avances en fabáceas: introducción. Pp. 101-102. In: Congresso Latinoamericano de Botânica, 6., 1994, Mar del Plata. Proccedings... Missouri Botanical Gardens Press, St. Louis.

Lopes, W. P.; Silva, A. F.; Souza, A. L. \& Meira-Neto, J. A. 2002. Estrutura fitossociológica de um trecho de vegetação arbórea no Parque Estadual do Rio Doce. Acta Botanica Brasilica 16(4): 443-456.

Lorenzi, H. 1992. Árvores brasileiras: manual de identificação e cultivo de plantas arbóreas nativas do Brasil. Plantarum, São Paulo.

Mansano, V. F. \& Tozzi, A. M. G. A. 1999. The taxonomy of some Swartzieae (Leguminosae, Subfam. Papilionoideae) from southeastern Brasil. Brittonia 51(2): 149-158. 
Mansano, V. F. \& Tozzi, A. M. G. A. 2001. Swartzia Schreb. (Leguminosae: Papilionoideae: Swartzieae): a taxonomic study of Swartzia acutifolia complex including a new name and a new species from Southeastern Brazil. Kew Bulletin 56(4): 917-929.

Mendonça Filho, C. V. 1996. Braúna, angico e jacarandá e outras leguminosas de mata atlântica: Estação Biológica de Caratinga, Minas Gerais. Fundação Botânica Margaret Mee; Fundação Biodiversitas, Belo Horizonte.

Mendonça Filho, C. V.; Forni-Martins, E. R. \& Tozzi, A. M. G. A. 2002. New chromosome counts in neotropical Machaerium Pers. species (Fabaceae) and their taxonomic significance. Caryologia 55(2): 111-114.

Paula, L. M. P. 1992. Fitossociologia e distribuição de pteridófitas do vinhático do Parque Florestal Estadual do Rio Doce: curso de campo. Relatório (não publicado), Belo Horizonte.

Pedralli, G.; Teixeira, M. C. B. \& França, E. G. 1986. Lauraceae do Parque Florestal do Rio Doce, Minas Gerais. Ciência e Cultura 38(8): 1414-1421.
Polhill, R. M. 1981. Papilionoideae. Pp. 191-425. In: Polhill, P. H. Raven (eds.). Advances in legume systematics. Royal Botanic Gardens, Kew.

Radford, A. E.; Dickison, W. C.; Massey, J. R. \& Bell, C. R. 1974. Vascular plant systematics. Harper \& Row, Publishers, New York.

Rizzini, C. T. 1977. Sistematização terminológica da folha. Rodriguésia 42: 103-125.

Rojo, J. P. 1972. Pterocarpus (Leg. Papilionaceae) revised for the World. Phanerogamarum Monographiae 5(3): 1-119.

Sartori, A. L. B. \& Tozzi, A. M. G. A. 1998. As espécies de Machaerium Pers. (Leguminosae-PapilionoideaeDalbergieae) ocorrentes no estado de São Paulo. Revista Brasileira Botanica 21(3): 211-246.

Scudeller, V. V. \& Carvalho-Okano, R. M. 1998. Bignonieae (Bignoniaceae) no Parque Estadual do Rio Doce, Minas Gerais, Brasil. Iheringia série Botânica 5(1): 79-133.

Tozzi, A. M. G. A. 1989. Estudos taxonômicos dos gêneros Lonchocarpus Kunth e Deguelia Aubl. no Brasil. Tese de Doutorado. Universidade Estadual de Campinas, Campinas. 